\title{
Modern Status of the Steppe Eagle Population in the Orenburg Region, Russia
}

\section{СОВРЕМЕННОЕ СОСТОЯНИЕ ПОПУЛЯЦИИ СТЕПНОГО ОРЛА В ОРЕНБУРГСКОЙ ОБЛАСТИ, РОССИЯ}

\author{
Karyakin I.V. (Center of Field Studies, N. Novgorod, Russia), \\ Zinevich L.S. (Koltzov Institute of Developmental Biology of Russian Academy of \\ Sciences, Moscow, Russia), \\ Nikolenko E. G. (Sibecocenter LLC, Novosibirsk, Russia) \\ Карякин И.В. (Центр полевых исследований, Н.Новгород, Россия), \\ Зиневич Л.С. (ФГБУН Институт биологии развития им. Н.К. Кольцова РАН, Москва, \\ Россия), \\ Николенко Э.Г. (ООО «Сибэкоцентр», Новосибирск, Россия)
}

\begin{abstract}
Контакт:
Игорь Карякин

Центр полевых

иссиедований

603109, Россия,

Нижний НовгороА,

ул. Нижегородская, 3-29

тел.: +7831433 3847

ikar_research@mail.ru

Аюдмила Зиневич ФГБУН Институт

биологии развития им. Н.К. Кольцова РАН 119334, Россия, Москва, ул. Вавилова, 26

тел.: +7 4991353322 , факс: +7 4991358012 lzinevich@gmail.com

Эльвира Николенко ООО "Сибэкоцентр" 630090, Россия, Новосибирск, а/я 547 тел.: +79231501279 elvira_nikolenko@mail.ru
\end{abstract}

Резюме

В статье приводятся результаты мониторинга степного орла (Aquila nipalensis) в Оренбургской области в 2010-2015 гг. 3а 2010-2015 гг. численность степного орла в Оренбургской области снизилась на 20,6 \%: с 369 (320-447) до 293 (266-349) пар. Средняя плотность распределения занятых гнездовых участков степного орла в 2015 г. в "янре" популяции (на кварцитовых грялах Зауралья) составияа 8,6/100 км², на остальной

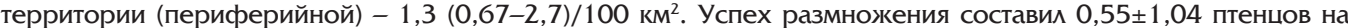

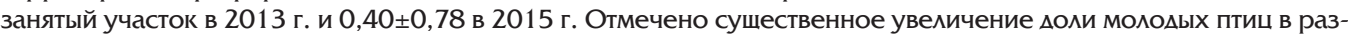
множаюшихся парах с 21,7 \% в 2012 г. до 44,4 \% в 2015 г. Основные угрозы степному орлу в Оренбургской области - степные палы и гибель на АЭП. Вероятно, что паление численности орлов связано и с усилением негативных факторов на путях миграции и местах зимовки.

Киючевые слова: пернатые хишники, хишные птицы, степной орёл, Aquila nipalensis, статус популяции, Оренбургская область.

Поступима в реАакцию: 18.11 .2016 г. Принята к публикации: 10.12.2016 г.

\section{Abstract}

The article presents the results of the Steppe Eagle (Aquila nipalensis) monitoring in the Orenburg region in 2010 2015. For 2010-2015 the population of Steppe Eagle in Orenburg region decreased by 20.6\% and is 266-349, at average 293 breeding pairs. In 2015 the average density of occupied breeding territories on the main part of the Steppe Eagle breeding population (Trans Ural - Western part of the region) in the Orenburg region was about 8.6 per $100 \mathrm{~km}^{2}$, in the other habitats of the low and middle density of species $-1.3(0.67-2.7) / 100 \mathrm{~km}^{2}$. Observed breeding success in 2013 is $0.55 \pm 1.04$, in 2015 is $0.40 \pm 0.78$ nestlings per occupied breeding territory. Substantial increase in the proportion of young birds in the breeding pairs from $21.7 \%$ in 2012 to $44.4 \%$ in 2015 was noticed. The main threats to the Steppe Eagle in the Orenburg region are steppe fires and death on power lines. It is likely that the decline of eagles' population is due to increasing of negative factors on the migration routes and wintering grounds.

Keywords: raptors, birds of prey, Steppe Eagle, Aquila nipalensis, status of the population, Orenburg region.

Received: 18/11/2016. Accepted: 10/12/2016.
Введение

Степной орёл (Aquila nipalensis) - угрожаемый вид, с 2015 г. занесённый в Красный Аист МСОП в категории «Endangered» (BirdLife International, 2015), вкАючённый в Красную книгу Российской Федерации (Галушин, 2001), являюшийся киючевым видом степного биома. В рамках реамизации проекта ПРООН/ГЭФ/Минприроды России "Совершенствование системы и механизмов управления ООПТ в степном биоме России" (Аалее "Степной проект"), членами Российской сети изучения и охраны пернатых хишников и сотрудника-

\section{Introduction}

Steppe Eagle (Aquila nipalensis) is endangered species listed in the IUCN Red List (BirdLife International, 2015), Red Data Book of the Russian Federation (Galushin, 2001), a key species of the steppe biome. It was chosen as indicator species for assessing the success in the implementation of the project of UNDP/GEF/Ministry of Natural Resources and Environmental Protection of the Russian Federation "Improving the Coverage and Management Efficiency of Protected Areas in the Steppe Biome of Russia" (hereafter "Steppe Project"). In the 


\section{Contact:}

Igor Karyakin

Center of Field Studies

Nizhegorodskaya str., 3-29

Nizhniy Novgorod,

Russia, 603109

tel.: +7831433 3847

ikar_research@mail.ru

Ludmila Zinevich Koltzov Institute of

Developmental Biology of Russian Academy of

Sciences IDB RAS

Vavilova str., 26

Moscow, Russia, 119334

tel.: +7 4991353322 ,

fax: +7 4991358012

Izinevich@gmail.com

Elvira Nikolenko

Sibecocenter LLC

P.O. Box 547

Novosibirsk

Russia 630090

tel.: +79231501279

elvira_nikolenko@mail.ru ми ООО "Сибэкоцентр" (Новосибирск) в 2010, 2012, 2013 и 2015 гг. проведены исследования гнездяшейся популяции степного орла в Оренбургской области. Результаты мониторинга 2010 г. и 2012 гг. приведены в отчётах, размешённых в сети Интернет (Карякин и Ар., 2010; Карякин и мр., 2012), результаты мониторинга 2012 г. также были опубликованы (Карякин и Ар., 2013). Аанная статья обобшает результаты мониторинга степного орла в Оренбургской области в 2013 и 2015 гг.

\section{Природные характеристика района исследований}

Территория Оренбургской области - это обширная, неоднородная по геологической истории и характеру рельесра территория, которая захватывает несколько физико-геограсических стран - от Восточно-Европейской равнины на запаце $\Delta о$ Турано-Тургайской страны на востоке.

Степная область Южного Урала занимает осевое положение в обследованном регионе. Истинный горный рельес здесь не выражен, морфологически территория в своей центральной части является приподнятым денудационным плато, прорезанным глубокими крутоскионными $\Delta$ линами основных рек (Мильков, Гвоздецкий, 1976). ОАнако по перисерии плато на большом протяжении вторично Аробно расчленено с образованием мелкосопочного рельесра (Крашенинников, 1939; Вербицкая, 1974). Приречный мелкосопочник зАесь, в своём типичном выражении - это лабиринт из беспорядочно или грядами расположенных горок (сопок) с крутыми вогнутыми или плоскими скионами, часто с островершинными гребнями, разделёнными каньонообразными Аолинами (горными баиками).

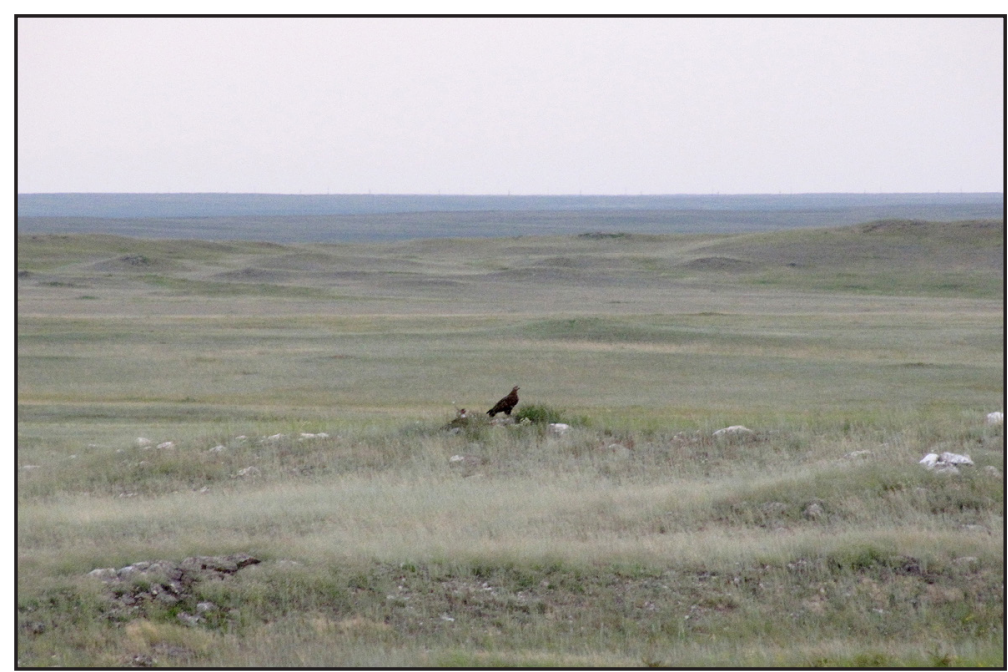

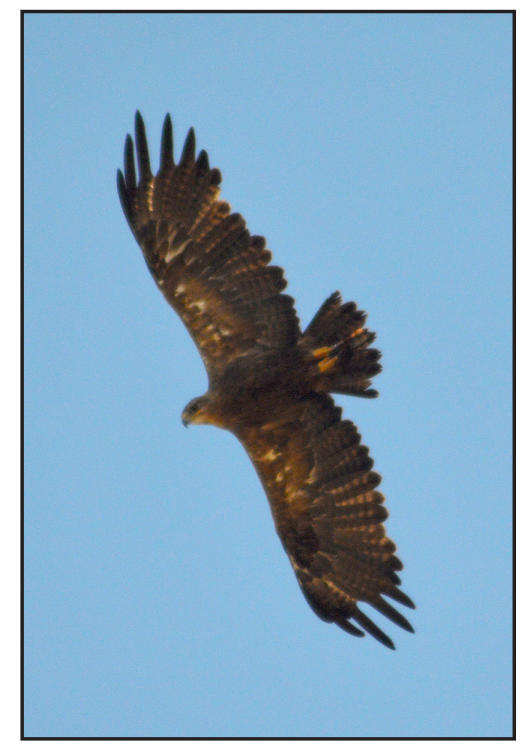

Степной орёл (Aquila nipalensis). Фото И. Карякина. Steppe Eagle (Aquila nipalensis). Photo by I. Karyakin.

framework of this project implementation, in 2010, 2012, 2013 and 2015 members of the Russian Raptor Research and Conservation Network, personnel of LLC "Sibecocenter" (Novosibirsk) and the Ornithological Laboratory of Eco-Center "Dront" (Nizhny Novgorod) studied the breeding population of the Steppe Eagle in Orenburg region. Monitoring results of 2010 and 2012 are given in reports on the Internet (Karyakin et al., 2010; Karyakin et al., 2012). Monitoring results of 2012 were also published (Karyakin et al., 2013.). This article summarizes the results of Steppe Eagle monitoring in the Orenburg region in 2013 and 2015.

\section{Methods}

The studies were carried out in accordance with the methodological recommendations on the monitoring organization of Steppe Eagle populations in Russia and Kazakhstan (Karyakin, 2012) and are described in detail in the article "Modern Status of the Steppe Eagle Population in Kalmykia, Russia" on the page 61 .

The first extensive study of the Steppe Eagle in the Orenburg region was conducted in 2010, at that time registration areas were

Типичные места гнездования степного орла в Восточном Оренбуржье. Фото И. Карякина.

Typical breeding habitats of the Steppe Eagle in the eastern part of the Orenburg region.

Photo by I. Karyakin. 


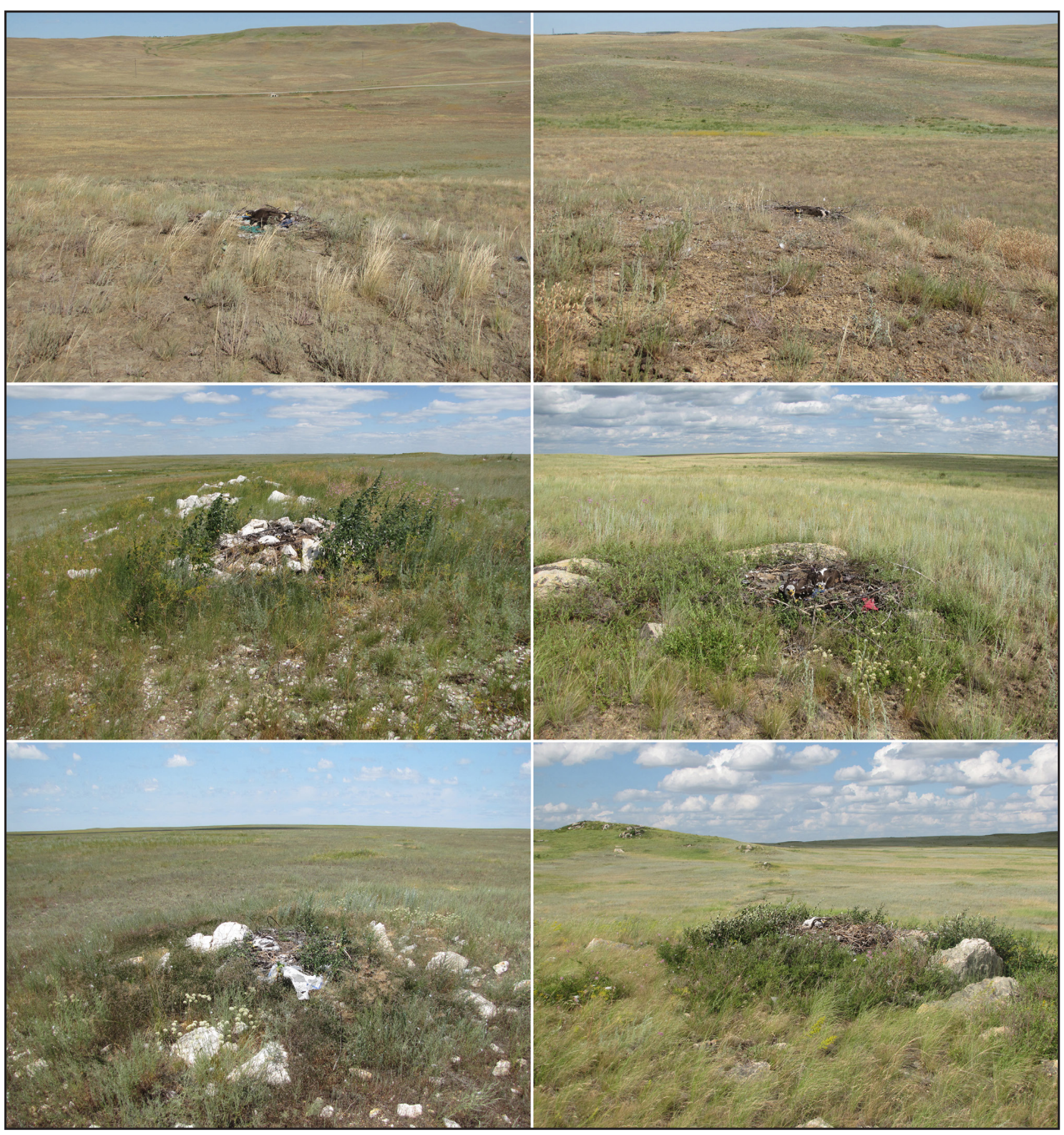

Типичные варианты размешения гнёз степного орла в Оренбургской области: вверху - Малая ХобАа, в центре и внизу - Восточное Оренбуржье. Фото И. Карякина.

Typical nest locations of the Steppe Eagle in the Orenburg region: at the top - Malaya Hobda, at the center and bottom - Eastern part of the Orenburg region. Photo by I. Karyakin.

Мелкосопочные массивы, в частности, широко развиты вАоль широтного отрезка $А$ омины р. Ураи. Переход от Предураиьского прогиба к запанному макроскиону Ураиьской горной страны отмечен появлением отдельных мелкосопочных массивов и изомированных останцовых гор, возвышаюшихся нац полого-волнистой равниной. Аалее к востоку местность приобретает сплошь мелкосопочный характер по обеим сторонам долины Урала. Правобережная часть made, which were examined in 2010 and 2012. (Karyakin et al., 2010; 2013). Subsequent monitoring of registration areas was carried out on July 1-6, 2013 and July 2-8, 2015. In 2013 three areas were examined: № 2 - valley of the River Karaganda, № 5 - Orlovskaya steppe and № 7 - KumakKokpektinskaya, in 2015 - 3 areas: № 5 Orlovskaya steppe, № 6 - Malaya Hobda and № 7 - Kumak-Kokpektinskaya (table 1, fig. 1). 
известна под названием Губерлинских гор, гАе Аостигается максимум абсолютных высот (свыше 430 м н.у.м., к северу - $\Delta$ о более 480 м н.у.м.), понижаюшихся к юго-востоку ( $\Delta$ о 200 м н.у.м. на террасе р. Орь) и к югу.

С переходом к восточному макроскиону Ураиьской горной страны мелкосопочник сменяется слабоволнистым плато Ураио-Тобольского междуречья. Большая часть его представляет собой цокольную денудационную равнину (пенеплен) с участками придоминного мелкосопочника (Наумов, 1960). Более или менее непрерывно мелкосопочные массивы тянутся по правому берегу Ураяа и севернее, но формы их здесь более сглажены и расчленение слабее. Пенепленизированный рельеср Урало-Тобольского плато также не искиючает начичия останцовых холмистых массивов и элювиаиьных развалов глыб коренных пород.

Западнее области Южного Урала лежит возвышенность Обший Сырт, сложенная осацочными породами. Центраиьная ось Обшего Сырта проходит от Приураиья $А$ о волжских террас с северо-востока на югозапад. Абсолютные высоты возвышенности снижаются к запауу (высшая точка Обшего Сырта 405 м н.у.м). От Низменного Заволжья к востоку возрастает также расчленённость рельесра, появляются такие его формы, как оползневые стенки и цирки, обнажения твёрдых пород, шиханы, а в предураиьской части Обшего Сырта - и мелкосопочные массивы низкогорного характера.

Южнее лежит Подураиьское плато - это обширная пластовая равнина, ограниченная с севера широтным отрезком реки Урац, с юга - Предустюртским понижением, на запаце переходяшая в Прикаспийскую низменность, а на востоке - в Мугоджары. Вся территория плато относится к Урало-Эмбенской солянокупольной области и отличается развитой соляной тектоникой (Колтыпин, 1957). Рельеср представляет собой пологоувалистую приподнятую равнину, расчленённую широкими Аолинами рек. Речные Аолины (особенно используюшие подножия куэст) резко асимметричны - обычно правый борт Аолины крутой, высокий, в плане фестончатый (Сваричевская, 1965; Матяшенко, 1985).

Главной рекой описываемого региона является Ураи, который принимает здесь несколько крупных притоков - справа Сакмару, а также Чаган, впахаюший уже в пределах Прикаспийской низменности, слева - Утву, Илек, Орь, Б. Кумак с Жарлы. Западная часть региона - Общий Сырт - представляет собой водораздел бассей-
The total area of monitoring grounds was $1,078.54 \mathrm{~km}^{2}$ in $2013,1,212.00 \mathrm{~km}^{2}$ in 2015.

According to the research results in 2012 (Karyakin et al., 2013) the area of habitats suitable for Steppe Eagle breeding in the Orenburg region was $6,871.5 \mathrm{~km}^{2}$.

According to GIS analysis of habitats and research in 2013 in Steppe Eagle breeding habitats in the Orenburg region the following zones were allocated: zone A - population nucleus with a high density nesting of $2,767.55 \mathrm{~km}^{2}$ (quartzitic ridges of TransUrals); and zone B - the rest part of the population, area of $4,103.95 \mathrm{~km}^{2}$ (fig. 2). These zones had separate extrapolation of density indicators from areas in the respective zones.

\section{Research results \\ Summary of previous years' results}

During the research 54 breeding territories of Steppe Eagles were found in the Orenburg region in 2010, habitable nests were found on 11 of them, 26 - occupied nests but abandoned because of non-breeding of birds or death of their brood, on 16 territories we met birds, but we could not find nests, and on 1 territory we found old, crumbling nests of Steppe Eagles, not occupied by birds for more than 5 years (fig. 3). Among 38 territories, confirmed by findings of nests, the successful breeding was registered only on $29 \%$ of them, and there was no successful breeding on $71 \%$. Nevertheless, virtually all territories were occupied by birds. It was impossible to confirm the occupation of 1 territory (2.6\%), and it was recorded as abandoned (Karyakin et al., 2010).

The density of breeding Steppe Eagles in all examined steppe areas was changed quite weak, varying from 1.95 to $5.31 / 100 \mathrm{~km}^{2}$, with an average of $2.88 / 100 \mathrm{~km}^{2}(2.26-3.68)$. Direct extrapolation of density in breeding territories of the Steppe Eagle in registration areas by steppe areas $\left(13,034.24 \mathrm{~km}^{2}\right) \mathrm{sug}$ gests that there is breeding in the Orenburg region of 294-479, an average of 375 pairs of Steppe Eagles, only 29.73 \% of which were successful at the time of examination, that is 87-142 pairs, 111 pairs at average (Karyakin et al., 2010).

In 2012 in the Orenburg Region 60 breeding territories of Steppe Eagles were examined, including 48 at the registration areas. Nests were found on areas on 43 breeding territories, on 34 - occupied: 16 are abundant, on two territories brood died at the 
нов Урала и Волги (последний представлен в Оренбургской части, прежле всего, бассейном р. Самара). Восточная часть региона - водораздел бассейнов Урала и Оби (Тобола). Иргизское и Подурамьское плато, лежашие преимушественно южнее Оренбургской области в Казахстане, служат водоразделами бассейна Урала с бессточными внутренними бассейнами Уияа и Сагиза, Иргиза и Тургая, а также небольшого бассейна р. Эмба, которая пересыхает, несколько не доходя Каспия.

Киимат региона резко континентаиьный, засушливый, с жарким летом и холодной малоснежной зимой, с большим размахом суточных и сезонных колебаний температур. В целом его континентаиьность возрастает с запала на восток - он становится более контрастным и засушливым. Годовая сумма осаАКОв составляет от 250 Ао 450 мм/гоА, она повышается с юга на север и с востока на запац. Испарение значительно превышает сумму осацков, например, мия метеостанции Орск более чем в 2,5 раза (800 и 300 мм/год, соответственно), мяя более южных частей региона - $А$ 10 раз. Большая часть осахков выпацает летом и связана с вторжениями цикионов, характерны сильные грозы. С Аругой стороны, летом часты засухи, отмечаются частые смерчи и пыльные бури (Атлас..., 1993; Ерохина, 1959).

ᄉеса в описываемой области привязаны к понижениям рельеса. По долинам рек распространены пойменные ивняки и черноольшанники, южнее - заросли лоха. На балочных и водораздельных скионах встречаются берёзовые и осиновые колки, особенно типичные мия южноураиьских мелкосопочников. Более или менее крупные массивы пойменных лесов (уремы) находятся только в Аолинах больших и средних рек (Урала, Илека, Б. Кумака, Ори, Губерли) (Имьина, 1964; 1970; Хомутова, 1956; 1965; Аохман, 1954; Сасрронова, 1980; Горчаковский, Рябинина, 1981; 1984; Матяшенко, 1985).

\section{Методика}

Исследования осушествлялись в соответствии с методическими рекомендациями по организации мониторинга попумяций степного орла в России и Казахстане (Карякин, 2012) и подробно описаны в статье "Современное состояние популяции степного орла в Каммыкии, Россия" на стр. 61.

Первые масштабные исследования степного орла в Оренбургской области были проведены в 2010 г., тогла же были заложены учётные плошахки, которые были планомер- stage of clutch, 18 - successful (fig. 4). All of 4 nests were successful in the period of fledgling leaving, but 2 of them were marked by partial death of brood - in first nest one egg of two was broken by bird, in second nest one of 2 nestlings at the age of six weeks was killed by quadruped predator. Occupation of breeding territories was $73.91 \%, 52.94 \%$ were successful nests on the number of occupied, and $41 / 86 \%$ - on the number of visited breeding territories (Karyakin et al., 2013).

The density of eagles breeding territories was $1.50-9.88 / 100 \mathrm{~km}^{2}$, at average of $5.06 / 100 \mathrm{~km}^{2}$. The density of occupied breeding territories averaged $4.20 / 100 \mathrm{~km}^{2}$. For the area of habitats suitable for breeding, excluding those where Steppe Eagle disappeared in recent years $\left(6,871.5 \mathrm{~km}^{2}\right)$, its population on nesting was in the range of 233 to 345 pairs, 289 pairs at average (Karyakin et al., 2013).

\section{The density on nesting and population} estimate in 2013

In 2013, in the Orenburg region 55 breeding territories of Steppe Eagles were identified, 46 breeding territories (83.64\%) were examined within 3 registration areas, $9(16.36 \%)$ - on transit routes (fig. 5). Indicators of breeding territories occupation are given in table 2 .

On the area № 2 - valley of the river Karaganda - in 2010 a group led by Bakka S.V. (see Karyakin et al., 2010) identified 4 Steppe Eagles breeding territories, one of which was successful - a habitable nest was found on it (in the remaining identified areas traces of birds presence were observed); the density of breeding territories was 2.69/100 $\mathrm{km}^{2}$ (fig. 3). In 2013, one occupied area was found on this territory - there was a pair of birds near the old nest (fig. 5). Currently, this breeding territory marks the north end of the eastern breeding group. Because of the general decline of population, there are only sporadic breeding pairs. Density (by one occupied territory) was 0.67 pairs $/ 100 \mathrm{~km}^{2}$, without successful nests.

On the area № 5 - Orlovskaya steppe in 20108 breeding territories were found, the density of which was $2.17 / 100 \mathrm{~km}^{2}$. In 2013, in this area among 7 examined breeding territories - 4 of them were occupied, inhabited nests with nestlings were in 2 of them (fig. 5). Three breeding territories of Steppe Eagles were abandoned. Density of occupied breeding territories was $0.75 / 100 \mathrm{~km}^{2}$. 
Табл. 1. Плошацки мия мониторинга гнездовой популяции степного орла (Аquila nipalensis) в Оренбургской области. Нумерация плошацок соответствует нумерации на рис. 1, 3-6.

Table 1. Surveyed areas (plots) for monitoring of the Steppe Eagle (Aquila nipalensis) breeding population in the Orenburg region). Numbers of plots in the table correspond to those in Fig. 1, 3-6.

\begin{tabular}{|c|c|c|c|c|c|c|}
\hline \multirow[b]{2}{*}{$\begin{array}{l}\text { No } \\
\mathbf{n} / \mathbf{n}\end{array}$} & \multirow[b]{2}{*}{$\begin{array}{l}\text { Название плошалки } \\
\text { Name of plot }\end{array}$} & \multirow{2}{*}{$\begin{array}{r}\text { Пиошамь, } \\
\mathbf{K M}^{2} \\
\text { Area, } \mathbf{k m}^{2}\end{array}$} & \multicolumn{4}{|c|}{ Иссленования / Surveys } \\
\hline & & & 2010 & 2012 & 2013 & 2015 \\
\hline 1 & $\begin{array}{l}\text { Ашисайская степь } \\
\text { Aschisayskaya steppe }\end{array}$ & 441.59 & & & & \\
\hline 2 & $\begin{array}{l}\text { Караганды (мелкосопочник } \\
\text { наА долиной реки) } \\
\text { Karagandy }\end{array}$ & 148.89 & & & & \\
\hline 3 & $\begin{array}{l}\text { Айтуарская степь } \\
\text { Aytuarskaya steppe }\end{array}$ & 307.77 & & & & \\
\hline 4 & $\begin{array}{l}\text { Буртинская степь } \\
\text { Burtinskaya steppe }\end{array}$ & 256.08 & & & & \\
\hline 5 & $\begin{array}{l}\text { Орловская степь } \\
\text { (мелкосопочник в } \\
\text { междуречье рр. Буртя и } \\
\text { Уртабуртя) } \\
\text { Orkovskaya steppe }\end{array}$ & 534.91 & & & & \\
\hline 6 & $\begin{array}{l}\text { Малая Хобла (степной } \\
\text { массив наА долиной реки) } \\
\text { Malaya Hobda }\end{array}$ & 282.35 & & & & \\
\hline 7 & $\begin{array}{l}\text { Кумак-Кокпектинская } \\
\text { (Ясный) } \\
\text { Kumak - Kokpekty (Yasnyi) }\end{array}$ & 394.74 & & & & \\
\hline 8 & Гирьял / Giryal & 143.12 & & & & \\
\hline 9 & $\begin{array}{l}\text { Приурацьский - Вязовка - } \\
\text { Мирный Путь } \\
\text { Priuralskiy - Vyazovka - } \\
\text { Mirnyi Put' }\end{array}$ & 167.28 & & & & \\
\hline 10 & $\begin{array}{l}\text { Губерля (Подгорное - } \\
\text { Киндерля-Вязовка) } \\
\text { Guberlya (Podgornoe - } \\
\text { Kinderlya-Vyazovka) }\end{array}$ & 160.10 & & & & \\
\hline
\end{tabular}

но обследованы в 2010 и 2012 гг. (Карякин и мр., 2010; 2013). Последуюший мониторинг учётных плошацок был осушествлён 1-6 июля 2013 г. и 2-8 июля 2015 г. В 2013 г. были исследованы 3 площадки: № 2 - $о$ оминой реки Караганды, № 5 - Орловская степь и № 7 - Кумак-Кокпектинская, в 2015 г. - 3 плошацки: № 5 - Орловская степь, № 6 - Маяая Хобла и № 7 - КумакКокпектинская (табл. 1, рис. 1).

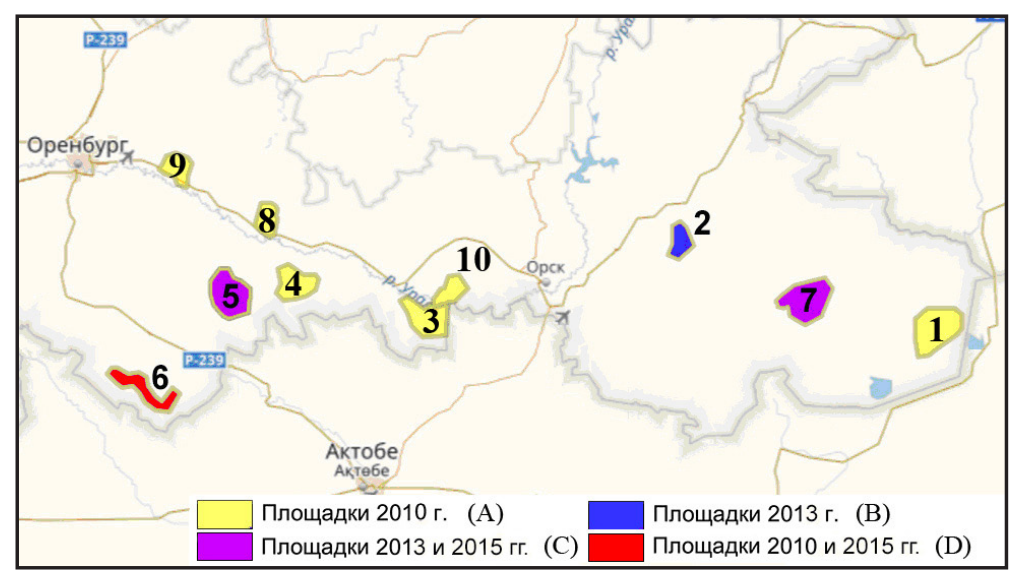

On the area № 7 - Kumak-Kokpektinskaya - in 2013, 37 out of 38 examined breeding territories were occupied, on 8 of which there were inhabited nests with nestlings, and 26 - abandoned nests with traces of death of brood or without them, but with traces of the birds presence, 1 territory was abandoned (fig. 5). Density of occupied breeding territories was $9.37 / 100 \mathrm{~km}^{2}$.

The average density of the occupied breeding territories on three areas was $3.89 / 100 \mathrm{~km}^{2}$ (1.61-9.43) (table 2). Error of weight-average and as a result, an asymmetric confidence interval are too large, due to the fact that the density of breeding pairs of eagles on Kumak-Kokpektinskaya area (area № 7) is much higher than on two other, proven in 2013. To get more reliable result, it is necessary to make separate recalculation of area of zone $A$ and $B$ (see methods and discussion below). However, for comparability of the results from studies of previous years, where the separate recalculation was not made, we need to estimate the population at average density of occupied breeding territories: extrapolation to the total area of the species' range in the Orenburg region $\left(6,871.5 \mathrm{~km}^{2}\right)$ gives an estimate of population of 267 (111-648) pairs occupying breeding territories. In 2010, this estimate was 375 (294-479) pairs, in 2012 - 289 (233-345) pairs.

\section{The density on nesting and population} estimate in 2015

In 2015, in the Orenburg region 75 Steppe Eagles breeding territories were examined, 59 of which $(78.67 \%)$ were examined within 3 registration areas, $16(21.33 \%)$ - on transit routes (fig. 6). Indicators of occupied breeding territories are given in table 3 .

On the area № 5 - Orlovskaya steppe - 4 out of 6 examined breeding territories were occupied, on 2 of which there were inhabited nests with nestlings, 1 was unsuccessful, 2 territories were abandoned (fig. 6). The density of occupied breeding territories was $0.75 / 100 \mathrm{~km}^{2}$.

Рис. 1. Пиошацки мия мониторинга гнездовой попумяции степного орла (Aquila nipalensis) в Оренбургской области. Нумерация плошацок соответствует нумерации в таблицах 1-7.

Fig. 1. Surveyed areas (plots) for monitoring of the Steppe Eagle (Aquila nipalensis) breeding population in the Orenburg region. Numbers of plots in the figure correspond to those in tables 1-7. 
Суммарная плошаць мониторинговых площадок составила в 2013 г. 1078,54 км², в 2015 г. - 1212,00 км². Таким образом, плошаць учётных плошацок составила в 2013 г. 15,70 \%, а в 2015 г. - 17,64\% от гнездового ареала вила в Оренбургской области (см. ниже).

Первый мандшастный анаяиз территории Оренбуржья и выделение местообитаний степного орла в области был проведён в 2010 г. (Карякин и мр., 2010). На тот момент плошадь гнездопригодных Аля степного орла местообитаний в Оренбургской области была оценена в 17178 км² $^{2}$ (52,27 \% от площади местообитаний вида в российской части трансграничной зоны России и Казахстана), 13034 км² без учёта овражно-балочных систем запада области, где степной орёл практически исчез на гнездовании в последние годы. По результатам исследований 2012 г. (Карякин и мр., 2013) эта плошаць была уменьшена на основании анаяиза распределения гнездовых участков на учётных площа$\Delta я \mathrm{x} \Delta \mathrm{O} 6871,5 \mathrm{~km}^{2}$ - т.е. в 2,5 раза. Такое уменьшение плошахи гнездопригодных мяя степного орла местообитаний оправдана тем, что часть местообитаний оказамась свободна от степного орла, даже там, гАе орлы ешё регистрировацись в 2010 г.

В 2012 г. было выявлено "ялро" наиболее плотной гнезАовой группировки степного орла на востоке Оренбургской области. 3Аесь была заможена Кумак-Кокпектинская мониторинговая площацка. Как оказалось, плотность распределения гнезАяшихся пар степных орлов здесь, более чем в 2 раза превышает плотность гнездования вида на остаиьной территории гнезАопригодных местообитаний в области.

На основании ГИС-анамиза местообитаний и исследований 2013 г. в гнездовом ареале степного орла в области были выделены зона А - ялро популяции с высокой плотностью гнезАования плошадью 2767,55 км² - это кварцитовые гряды 3аураиья, биотопы наиболее близкие к таковым в Запанном Казахстане, гле сосредоточена максимальная численность вида; и зона В - остальная часть популяции, площадью 4103,95 км² (рис. 2).

В настояшем исседовании мя оценки численности вила на эти территории были пересчитаны показатели плотности за все годы исслеАований 2010-2015: пиотность с Кумак-Кокпектинской учётной пиошахки экстраполироваии на плошаць зоны А, плотность на остаиьных учётных пиошадках усреАняли и экстраполироваии на плошаць зоны В.
On the area № 6 - Malaya Hobda - 7 out of 14 examined breeding territories were occupied, on 4 of which there were inhabited nests with nestlings and 2 were unsuccessful, 7 territories - abandoned (fig. 6). The density of occupied breeding territories was $2.48 / 100 \mathrm{~km}^{2}$ (15 breeding territories were identified in this area in 2010 (fig. 3), and the density was $5.31 / 100 \mathrm{~km}^{2}$ ).

On the area № 7 - Kumak-Kokpektinskaya - 34 out of 39 examined breeding territories were occupied, on 7 of which there were inhabited nests with nestlings and 24 nests were unsuccessful, 5 territories abandoned (fig. 6). The density of occupied breeding territories was $8.61 / 100 \mathrm{~km}^{2}$.

The average density of occupied breeding territories was $3.71 / 100 \mathrm{~km}^{2}(1.72-8.04)$ - asymmetric confidence interval was also very large. Population estimate at average was 255 (118-552) pairs that occupied breeding territories.

\section{Age structure of breeding birds}

In 2015, at breeding territories we were able to determine the age of 18 adult birds, 8 of which were younger than 5 . The proportion of young partners in breeding pairs was $44.4 \%$.

In 2012 the age was determined in 23 adult birds in nesting pairs, 5 of which or $21.7 \%$ were partners younger than 5 , i.e. in fact 2 times less than in 2015.

It should be noted that for the whole cross-border area of Russia and Kazakhstan the proportion of young birds in breeding pairs was $49.2 \%$ in 2012 (Karyakin et al., 2013).

\section{Broods and breeding productivity}

Analysis of breeding indicators (tables 4, 5) shows that the population decline correlates with extremely low indicators: each year steppe territory is affected by fires in the nesting period - in all the years of research burned-out nests were recorded, also with clutches and broods.

In 2010, in 10 nests with feathered nestlings there was $1-2$ nestlings, at average $1.6 \pm 0.52$ nestling per the successful nest $(n=37) 0.43 \pm 0.77$ nestlings per the occupied nest. Broods with two nestlings dominated $-60.0 \%$. It is reliably known that one brood died in one nest and 8 nests were burned during fires, probably also with clutches or nestlings (Karyakin et al., 2010).

In 2012, the number of nestlings in broods at the time of leaving varied from 1 


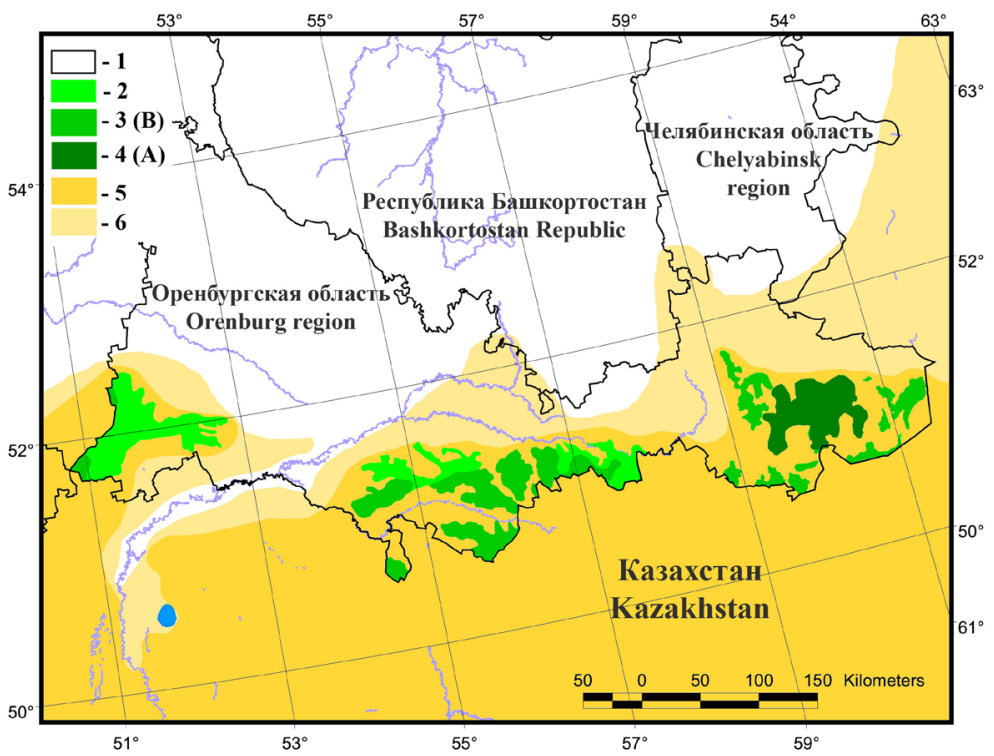

Pис. 2. Гнездопригодные местообитания степного орла в Оренбургской области. Условные обозначения: 1 - границы субъектов РФ, 2 - степные местообитания, в которых возможно гнездование отдельных пар, 3 - местообитания, в которых сосредоточены гнездовые группировки степного орла с низкой и средней плотностью распределения гнездяшихся пар (зона В), 4 - местообитания, в которых наблюдается высокая плотность распределения гнездяшихся пар (зона А), 5 современный гнездовой ареаи степного орла, 6 - область гнездования степного орла в конце 90-х гг. XX столетия - начале XXI столетия, на которой в настояшее время виА исчез.

Fig. 2. The Steppe Eagle habitats in the Orenburg region. Legend: 1 - administrative borders, 2 - steppe habitats, where some pairs can breed, 3 -habitats, where the density of the Steppe Eagle breeding pair distribution is low and middle (zone B), 4 - habitats, where the density of the Steppe Eagle breeding pair distribution is high (zone A), 5 - modern breeding range of the Steppe Eagle, 6-breeding range of the Steppe Eagle at the end of 1990-s - beginning of 2000-s, where the species has extinct now. to 3 , averaging $(n=18) 1.94 \pm 0.80$ nestlings per the successful nest $(n=34) 1.03 \pm 1.14$ nestlings per the occupied nest (Karyakin et al., 2013).

In 2013, 10 out of 40 occupied territories at the time of examination had inhabited nests, the number of nestlings in the brood varied from 1 to 3 , averaging $(n=22)$ $2.20 \pm 0.79$ nestlings per nest with brood, and $(n=40) 0.55 \pm 1.04$ nestlings per occupied breeding territory.

In 2015, the situation was similar: 13 out of 45 occupied territories had inhabited nests, 11 - with nestlings, two with clutches (belated, because the examination was in the beginning of July). The number of nestlings in brood varied from 1 to 3 , at average $(n=18) \quad 1.50 \pm 0.80$ nestlings per nest with brood, and $(n=45) 0.40 \pm 0.78$ nestlings per occupied breeding territory. Outside the plot in this year in the Orenburg region was discovered the first brood with 4 nestlings!

\section{Comparison of indicators for years of research}

Reliable dynamics (as far as it can be reliable in estimating the average density) can be seen in the results of 2012, 2013 and 2015 - the population decline was $11.8 \%$ for 3 years. Density indicators of breeding pairs at separate areas are reduced uniformly: on the area Malaya Hobda - more than 2 times, in Orlovskaya steppe - almost 3 times, in the valley of river Karaganda the Steppe Eagle virtually disappeared since 2010. And only the population nucleus has remained more or less stable in 2012-2015. The density of occupied territories was a little higher in 2013 than in 2012 and 2015.

For a more accurate Steppe Eagle population estimate we made separate recalculation of densities for population nucleus (zone A) and the rest (zone B) (table 8). In order received data in 2013 and 2015 can be compared with the data of 2010 and 2012, data from these years were also extrapolated separately to zones A and B.

The negative trend is $\mathbf{2 0 . 6} \%$, despite a stable situation on the area in the "nucleus" of the population. The rate of population decline is close to that, estimated for 20062012, which was $-18.75 \%$.

Decline in density of eagles at areas in zone B indicates that a population "is melting" in the periphery, despite the fact that its nucleus is quite stable. However, we cannot say that the same high density is 


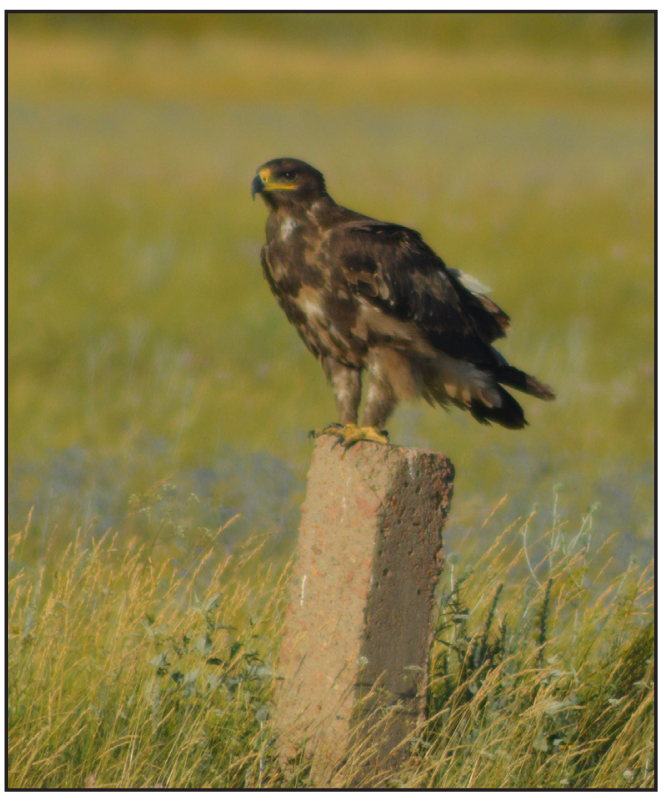

маховых (Clark, 1996; Forsman, 2008; Kaрякин, 2012). Если не удавалось идентисицировать возраст птиц $\Delta$ О гоАа, то Аля них определялся возрастной диапазон \pm 1 год по предложенной ранее определительной таблице, мибо по наличию ювенильных признаков птица относилась к возрастной группе млазше 5 лет или старше (см. Карякин и $\Delta$ р., 2013).

Математическую обработку данных осушествляли в MS Excel 2003 и Statistica 10. Аля плотности распределения гнездяшихся степных орлов приводится средневзвешенное значение \pm SE и несимметричный Аоверительный интерваи (Карякин, 2004; 2012), мяя показателей размножения приводятся среднее значение \pm SD.

\section{Историческая справка о степном орле в Оренбургской области и на примега- ющих территориях}

В последней четверти XIX века степной орёл был обычен в Оренбуржье. Его гнёзда находили в степях Обшего Сырта и верховьев Самары, по рекам Саммыш и Аонгуз, в бассейне р. Илек, в окрестностях Оренбурга (Зарудный, 1888; 1897). На востоке области степной орёл регистрировался как обычный гнездяшийся виА Ао середины XX столетия (Nazarov, 1886; Райский, 1951). По Аанным А.В. Аавыгоры (1998) в 80-90-х гг. XX столетия северная граница гнездового ареала степного орла в Оренбуржье проходила левобережной Аолиной р. Самара, южнее Бузулука и Оренбурга, дамее к востоку по северному подножию водораздельных хребтов Ура^о-Илекского межАуречья, а в восточной части области - по северному пределу
Степной орёл на присахе. Фото И. Карякина. Steppe Eagle on the perch. Photo by I. Karyakin.

maintained throughout the whole zone A, probably there is decline at the edges, without touching for the last 3 years the territory of Kumak-Kokpektinskaya area.

The obvious fact of deterioration of the situation is juvenation of breeding groups against the population decline that we see by comparing the age of the birds in the breeding pairs and dynamics of occupied breeding territories in 2012 and 2015, mainly in Kumak- Kokpektinskaya area.

\section{Conclusions}

1. During 2010-2015 Steppe Eagle population in the Orenburg region decreased by $20.6 \%$, from $369(320-447)$ to 293 (266-349) pairs.

2. The average density of occupied Steppe Eagle breeding territories in 2015 in the "nucleus" of the population (in the quartzitic ridges of Trans-Urals) was $8.6 / 100 \mathrm{~km}^{2}$, and the rest of the territory (peripheral) - $1.3(0.67-2.7) / 100 \mathrm{~km}^{2}$. In the "nucleus" of the population more than $80 \%$ of Steppe Eagle pairs.

3. Density of breeding pairs of eagles at the area in the "nucleus" of the population remains stable during the last 3 years, whereas in the rest of the territory in these three areas the breeding density has fallen by $2-4$ times over 5 years. Peripherals loses Steppe Eagles much faster than the "nucleus" - the population "is melting" at the edges and still remains more or less stable in the center.

4. The density of breeding pairs remains low: in 2013 and 2015 - in "nucleus" of the population 2.0 and 1.8 pairs $/ 100 \mathrm{~km}^{2}$ respectively, the rest of the territory -0.29 and 0.73 pairs $/ 100 \mathrm{~km}^{2}$ respectively.

5. Breeding success was $0.55 \pm 1.04$ nestlings per occupied territory in 2013 and $0.40 \pm 0.78$ in 2015. That is, after 2012 breeding success is definitely reducing.

6. A substantial increase has been recorded in the proportion of young birds in breeding pairs from $21.7 \%$ in 2012 to $44.4 \%$ in 2015 . The good news is that the resource of young birds is still kept in the population; they are able to re-establish the failed pair of old birds, even due to inflow from Kazakhstan. But the trend itself gives no grounds for optimism. 


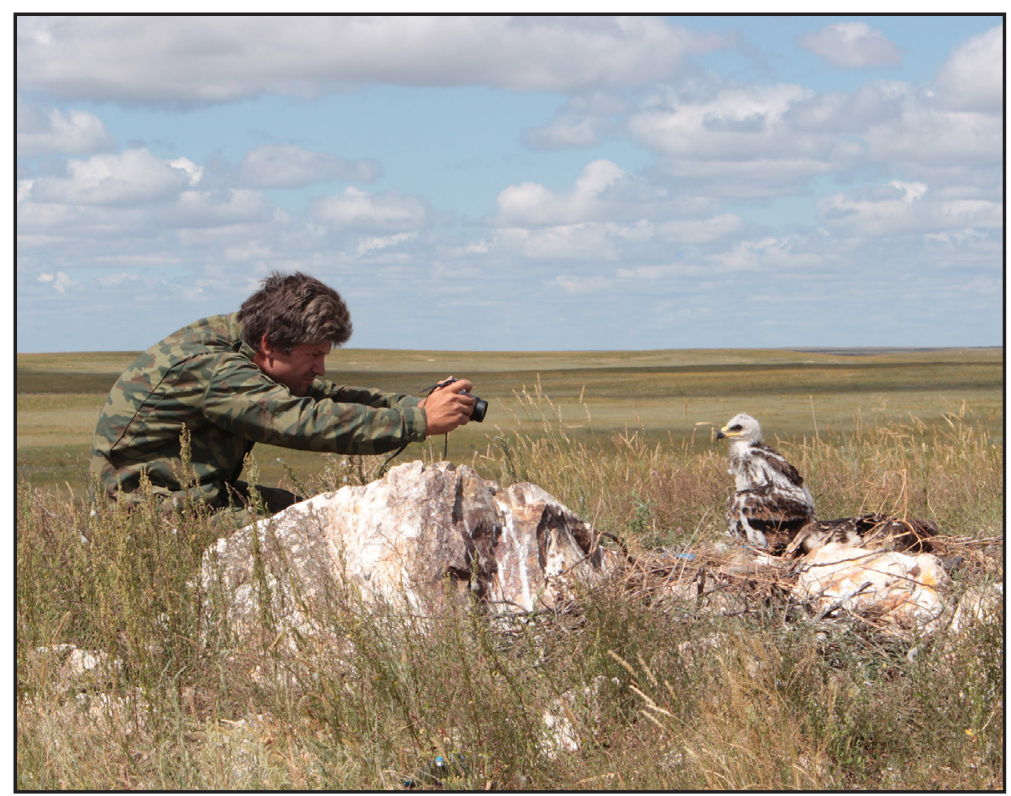

степей; гнездование вида было установлено в Первомайском, Оренбургском, Соль-Илецком, Акбулакском, Беляевском, Кувандыкском и Светлинском районах (Аавыгора, 1985; 1992; Чибилев, 1995). При этом отдельные пары степных орлов в этот период гнездились в степных анкиавах на юго-запаце Башкирии (Карякин, 1998) и юго-востоке Челябинской области (Карякин, Козлов, 1999) близ границы с Оренбуржьем.

В первой половине 1980-х гг. плотность распределения гнездящихся пар степного орла в южных районах Оренбургской области составляла 4,1-8,2 пар/100 км² обшей плошаАи, но уже в 1990-е гг. вид исчез на гнездовании во многих местах, что послужило Аоказательством к устойчивой тенденции снижения численности степного орла на территории Оренбуржья ( $\Delta \mathrm{a}-$ выгора, 1998).

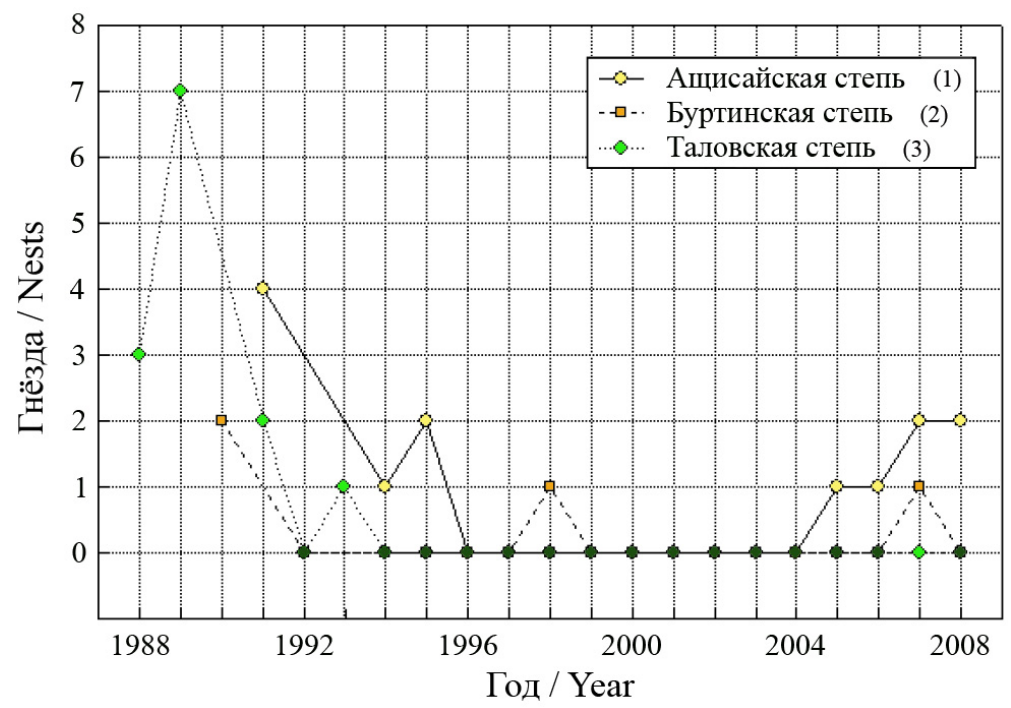

Обследование гнезда степного орла.

Фото 1 . Зиневич.

Survey of the Steppe Eagle nest. Photo by L. Zinevich.

К концу 1990-х гг. численность вида в области была оценена в 200-300 гнездяшихся пар (Аавыгора, 1998), что определенно занижено как минимум в 3 раза на тот период времени. Тем не менее, негативная динамика численности степного орла в Оренбуржье очевинна, так как по результатам исследований 2000-2004 гг. уже было установлено исчезновение вида на гнездовании в Башкирии и Челябинской области и откат северной границы гнездового ареала на юг на 100 км (Карякин, 2013).

$\triangle$ инамика численности степного орла в Оренбургском заповеднике, киастеры которого распределены по всей степной зоне области от самой запанной границы (Тамовская степь) Ао востока (Ашисайская степь), красноречиво имююстрирует ситуация с видом в областив целом.

Наиболее стабильное гнездование наблюдается лишь в Ашисайской степи на востоке области. 3Аесь в период с 1989 по 2008 г. численность изменялась от 0 Ао 4 гнездяшихся пар в год; максимамьная гнезАовая численность (4 гнезда) наблюдалась в конце 1980-х - начале 1990-х годов (Самигулин, 1996), далее последовало снижение, и с 1996 по 2004 г. степные орлы встречаиись на участке, но, по-видимому, не гнездились, а с 2005 по 2008 г. наблюАается восстановление гнездовой численности, которая, однако, пока не Аостигма предылуших максимумов (Барбазюк, 2009).

В Буртинской степи максимаиьные значения гнездовой численности (2 гнезАа) наблюдамись на рубеже 1980-1990-х гг. прошлого века (Самигулин, 1996) и с начала 1990-х гг. гнездование степных орлов на территории Аанного участка стало случайным. (Барбазюк, 2009).

Количество гнёзд степных орлов на трёх участках заповедника "Оренбургский" за период 1988-2008 гг. (по: Барбазюк, 2009).

Total number of the Steppe Eagle nests in the three areas of the Orenburgsky State Nature Reserve for the period 1988-2008 (from: Barbazyuk, 2009). 

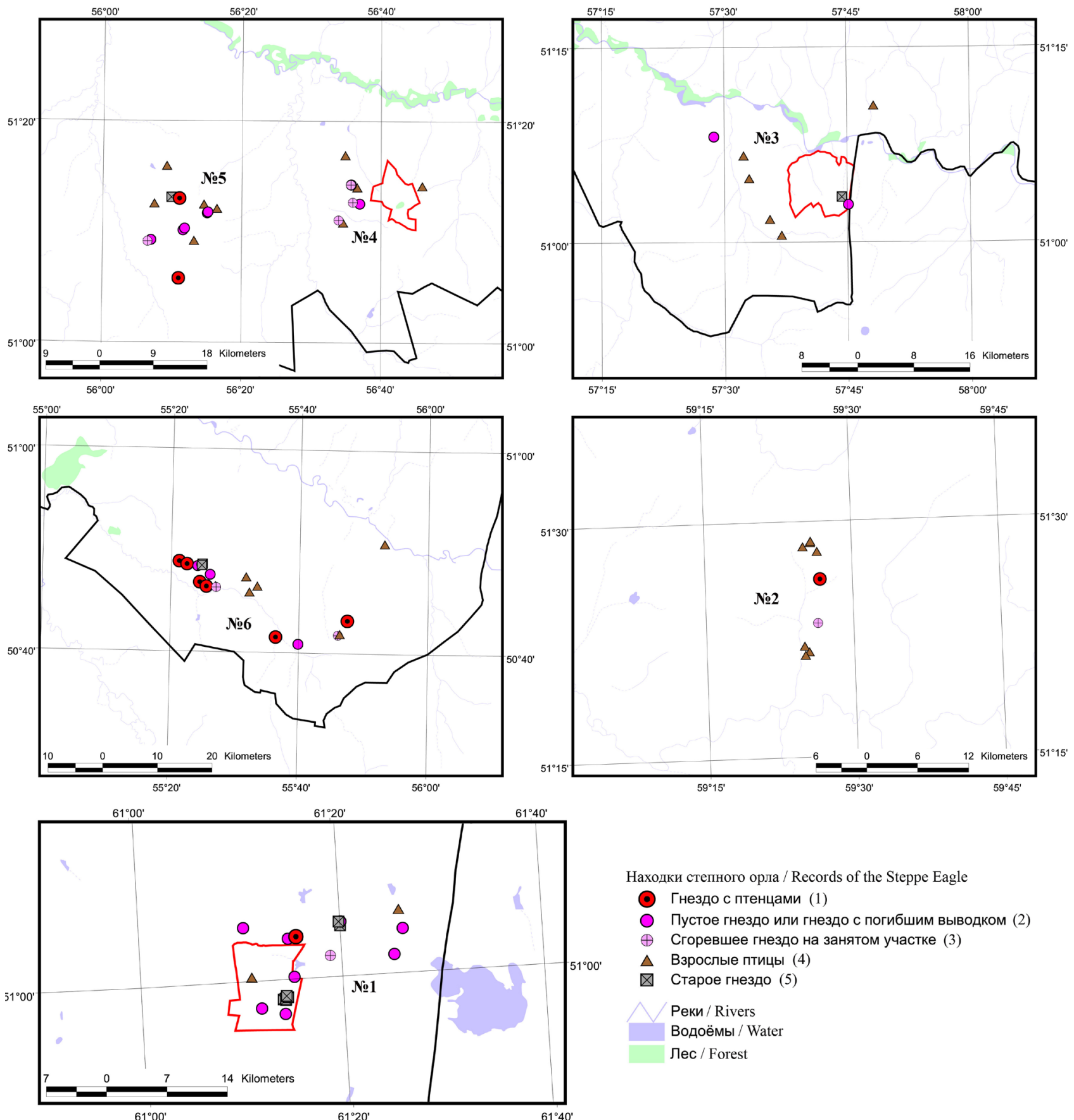

Находки степного орла / Records of the Steppe Eagle

(-) Гнездо с птенцами (1)

Пустое гнездо или гнездо с погибшим выводком (2)

$\oplus$ Сгоревшее гнездо на занятом участке (3)

$\triangle$ Взрослые птицы (4)

Ф Старое гнездо (5)

Реки / Rivers

Водоёмы / Water

Лec / Forest

Рис. 3. Выявленные гнездовые участки степных орлов в Оренбургской области на площахках и в их окрестностях, обследованных в 2010 г., из: Карякин и Ар., 2010. Нумерация площацок соответствует нумерации в таблицах 1-7.

Fig. 3. Discovered breeding territories of the Steppe Eagle in the Orenburg region on the plots and in their neighborhoods surveyed in 2010, from Karyakin et al., 2010. Legend: 1 - nest with nestlings, 2 - empty nest or nest with dead nestlings, 3 - nest burned in a fire on the occupied breeding territory, 4 - adult birds, 5 - old nest unoccupied by adult birds. Numbers of plots in the figure correspond to those in tables $1-7$.

В Таловской степи (самом запанном киастере заповедника, расположенном на границе с Самарской областью), на рубеже 1980-1990-х гг. прошлого века плотность гнездования степных орлов составляла 0,06 пар/1 км², или 2 гнезда в перерасчете на территорию Аанного участка, и являлась максимальной мля всех четырёх участков заповедника на данный период времени (Самигулин, 1996). Но при этом в 1989 г. зАесь было найдено 7 гнёзд степных орлов с киацками (Симак, 1990). С 1994 года степные орлы перестами гнездиться в Таловской степи, несмотря на регулярные встречи отдельных особей в гнездовой сезон (Барбазюк, 2009). Интересно, что аналогичным образом скиаАывалась Аинамика численности степного орла на территории Самарской области, с которой непосредственно граничит Талов- 
ская степь. В начале XXI столетия в овражно-балочной сети Синего Сырта численность степного орла в соседней Самарской области была оценена в 50 пар (45-55 пар). Однако обследование Синего Сырта в 2007 г. показаио 4-кратное сокрашение численности степного орла на гнездовании. В долинах рек Иргиз и Ростоши были проверены 8 гнездовых участков орлов, обнаруженных ранее, и мишь 2 из них оказаиись занятыми птицами, причём успешное размножение (гнездо с 2-мя птенцами) было зарегистрировано мишь на одном участке. Плотность распределения на гнездовании степного орла составила 1.8 пар/100 км² гнездопригодной пиошади, 0.5 пар/100 км² общей плошади, а численность гнезАовой группировки степного орла на Синем Сырте сократилась до 25-35 пар (Карякин, 2008; Карякин, Паженков, 2008). В современный период здесь численность степного

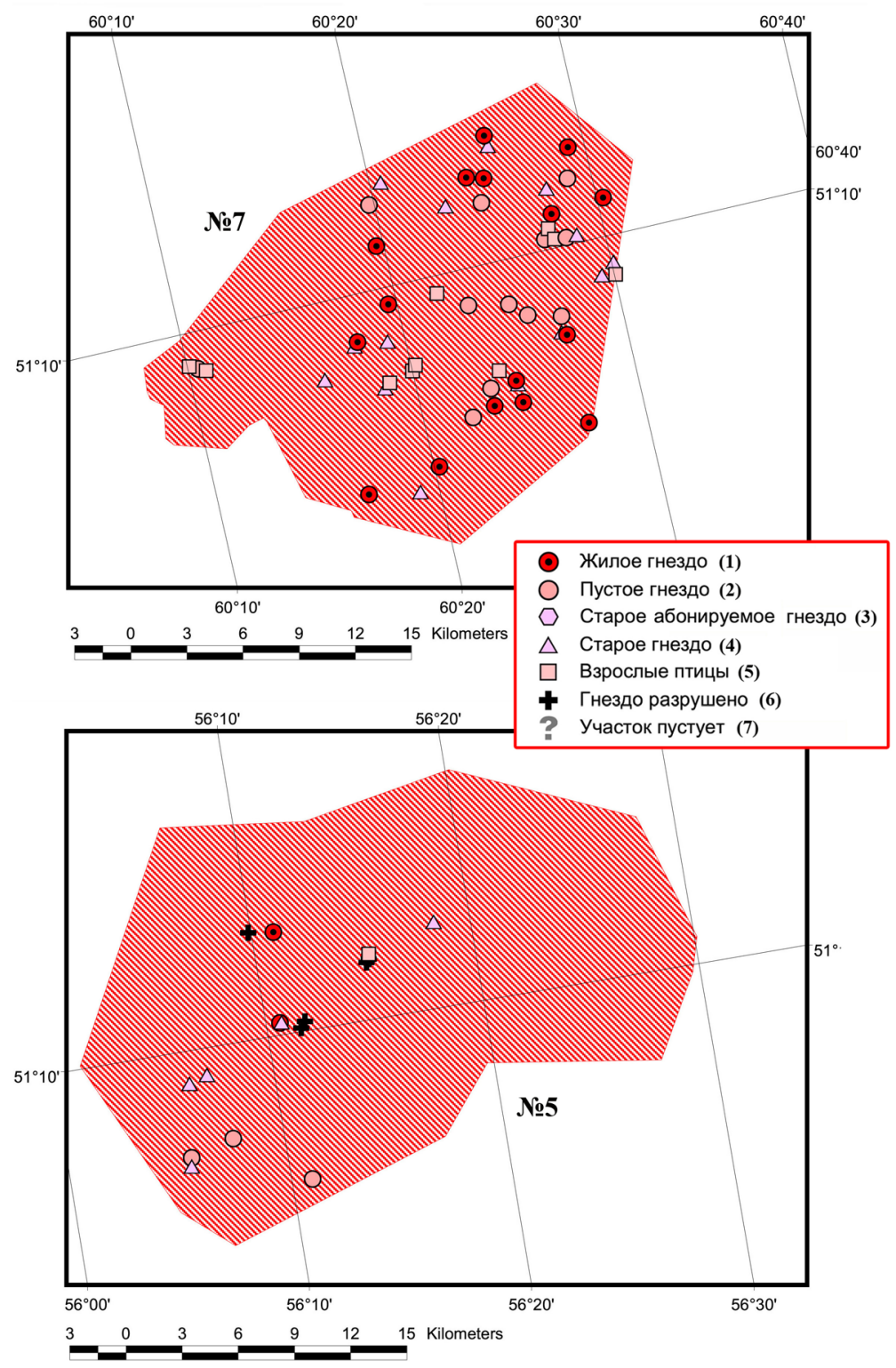

орла сократилась ешё сильнее и на контрольной территории остаётся гнездиться единственная пара орлов.

В Айтуарской степи в период 1989-1994 гг. плотность гнездования степных орлов составляла 0,02 пары/1 км² (Самигулин, 1996), или 2 гнезда в перерасчете на территорию Аанного участка, но позже вид перестаи здесь гнездиться (Барбазюк, 2009).

\section{Результаты исследований \\ Краткие результаты исследований прошлых лет}

В ходе исследований 2010 г. на территории Оренбургской области было выявлено 54 гнездовых участка степных орлов, на 11 из которых обнаружены жилые гнёзда, на 26 - гнёзда занятые, но пустуюшие по причине неразмножения птиц или гибели их потомства, на 16 участках встречень птицы, но гнёзд обнаружить не удамось и на 1 участке обнаружены старые, разваииваюшиеся гнёзаа степных орлов, не занимавшиеся птицами уже более 5 лет (рис. 3). Из 38 участков, подтвержлённых находками гнёзА, мишь на 29 \% зарегистрировано успешное размножение, а на $71 \%$ успешное размножение отсутствовало. Тем не менее, практически все участки оказаиись занятыми птицами. Аишь мия еАинственного участка (2,6 \%) подтвердить его занятость не удалось, и он был отнесён в категорию покинутых (Карякин и Ар., 2010).

Плотность распределения гнездовых участков степного орла во всех осмотренных степных массивах изменялась Аостаточно слабо, варьируя от 1,95 Ао 5,31/100 км², составляя в среднем 2,88/100 км² (2,26-3,68). Прямая экстраполяция плотности распределения гнезАовых участков степного орла с учётных площалок на плошаць степных массивов без учёта овражно-балочных систем запаха области (13034,24 км²) позволила предположить гнездование в Оренбург-

Рис. 4. Выявленные гнездовые участки степных орлов в Оренбургской области на площанках и в их окрестностях, обследованных в 2012 г. Нумерация пиошацок соответствует нумерации в таблицах 1-7.

Fig. 4. Discovered breeding territories of the Steppe Eagle in the Orenburg region on the plots and in their neighborhoods surveyed in 2012. Legend: 1 - living nest (nest with clutch or brood), 2 - empty nest or nest with dead clutch or brood, 3 - old nest occupied by adult birds, 4 - old nest unoccupied by adult birds, 5 - adult birds, 6 - destroyed nest, 7 - abandoned breeding territory. Numbers of plots in the figure correspond to those in tables $1-7$. 
ской области 294-479, в среднем 375 пар степных орлов из которых мишь 29,73 \% были успешными на момент проверки, что составляет 87-142 пар, в среднем 111 пар (Карякин и Ар., 2010).

В 2012 г. в Оренбургской области осмотрено 60 гнездовых участков степных орлов, в том числе 48 на плошадках. На плошалках на 43-х участках обнаружены гнёзда, в том числе на 34-х - занятые: на 16 пустые, в 2-х из которых Аостоверно погибло потомство на стаАии киацки, на 18 - успешные (рис. 4). Из 4-х повторно посешавшихся гнёзд в период вылета слётков все оказамись успешными, но на 2-х отмечена частичная гибель потомства - в одном гнезде из 2-х яиц одно было разбито птицей, в Аругом гнезде один из 2-х птенцов в полуторамесячном возрасте убит четвероногим хишником. Занятость гнездовых участков составила 73,91 \%, успешными оказались 52,94 \% гнёзд от числа занятых и 41,86 \% - от числа посешавшихся гнезАовых участков (Карякин и Ар., 2013).

Плотность распределения гнездовых участков с учётом пустуюших (за вычетом площацок с нулевыми значениями) составима 1,50-9,88/100 км², в среднем 5,06/100 км². Плотность распределения занятых гнездовых участков составила в среднем 4,20/100 км². Аяя скорректированной плошади гнезАопригодных местообитаний, за вычетом территорий, на которых степной орёл исчез за последние годы $(6871,5$ $\mathrm{Kм}^{2}$ ), его численность на гнездовании оценена в диапазоне от 233 до 345 пар, в среднем 289 пар (Карякин и др., 2013).

Пиотность распределения на гнезцовании и оценка численности в 2013 году

В 2013 г. в Оренбургской области выявлено 55 гнездовых участков степных орлов, 46 гнездовых участков (83,64\%) осмотрено в пределах 3-х учётных площаАок, 9 (16,36 \%) - на транзитных маршрутах (рис. 5). Показатели занятости гнезАовых участков приведены в таблице 2 .

На площадке № 2 - долина р. КараганАы - в 2010 г. группой поА руководством С.В. Бакки (см. Карякин и Ар., 2010) было выявлено 4 гнездовых участка степных орАов, один из которых оказался успешным - на нём найдено жилое гнездо (на остальных выявленных участках были отмечены следы пребывания птиц); плотность распределения гнездовых участков составила 2,69/100 км² (рис. 3). В 2013 г. на этой плошадке был выявлен мишь один занятый

Табл. 2. Показатели занятости гнездовых участков степного орла на площадках Оренбургской области в 2013 г. Нумерация плошацок соответствует нумерации на рис. 1, 3-6.

Table 2. Occupation of the Steppe Eagle breeding territories on the plots of the Orenburg region in 2013. Numbers of plots in the table correspond to those in fig. 1, 3-6.

\begin{tabular}{|c|c|c|c|c|c|c|c|c|c|c|c|c|}
\hline Noo & $\begin{array}{l}\text { Наименование } \\
\text { плошахки Name of } \\
\text { plot }\end{array}$ & 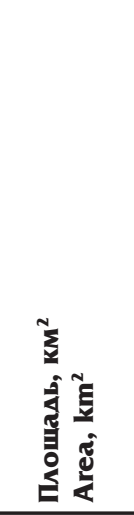 & 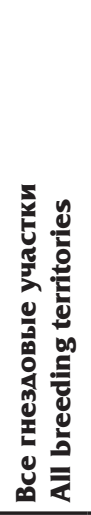 & 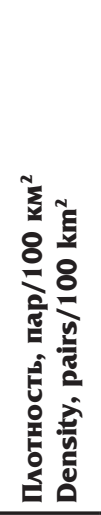 & 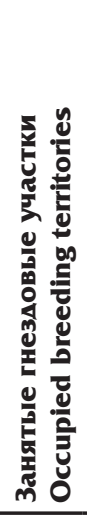 & 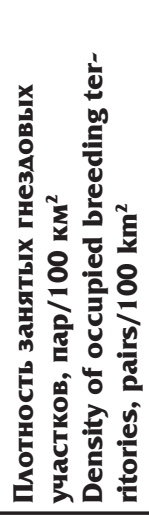 & 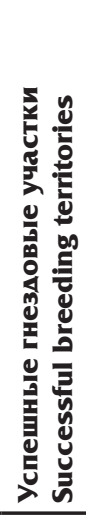 & 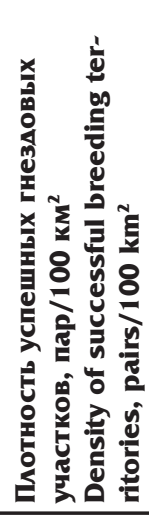 & 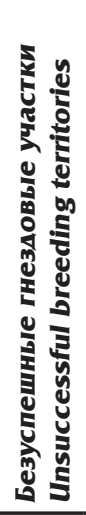 & 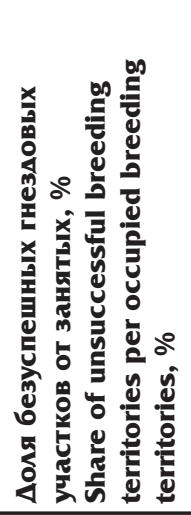 & 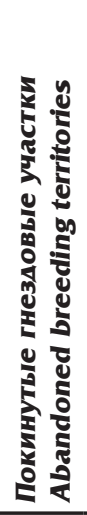 & 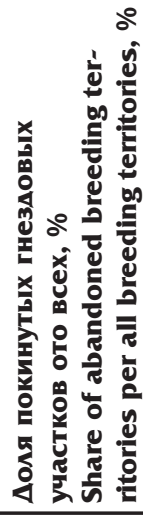 \\
\hline 2 & $\begin{array}{l}\text { Аолина р. Караганды } \\
\text { Karagandy }\end{array}$ & 148.89 & 1 & 0.67 & 1 & 0.67 & 0 & 0 & 1 & 100.00 & 0 & 0.00 \\
\hline \multirow[t]{2}{*}{5} & $\begin{array}{l}\text { Oрловская степь } \\
\text { Orkovskaya steppe }\end{array}$ & 534.91 & 7 & 1.31 & 4 & 0.75 & 2 & 0.37 & 2 & 50.00 & 3 & 42.86 \\
\hline & $\begin{array}{l}\text { Bcero / Cреднеe } \\
\text { Total / Average }\end{array}$ & 683.80 & 8 & $\begin{array}{c}1.17 \\
(0.86- \\
1.60)\end{array}$ & 5 & $\begin{array}{c}0.73 \\
(0.98- \\
0.78)\end{array}$ & 2 & $\begin{array}{r}0.29 \\
(0.16- \\
0.55)\end{array}$ & & & & \\
\hline \multirow[t]{2}{*}{7} & $\begin{array}{l}\text { Кумак-Кокпектинская } \\
\text { Kumak - Kokpekty }\end{array}$ & 394.74 & 38 & 9.63 & 37 & 9.37 & 8 & 2.03 & 26 & 70.27 & 1 & 2.63 \\
\hline & $\begin{array}{l}\text { Всего / Среднее по } \\
\text { трем пиощамкам } \\
\text { Total / Average on } \\
\text { three plots }\end{array}$ & 1078.54 & 46 & $\begin{array}{r}4.27 \\
(1.89- \\
9.61)\end{array}$ & 42 & $\begin{array}{r}3.89 \\
(1.61- \\
9.43)\end{array}$ & 10 & $\begin{array}{r}0.93 \\
(0.43- \\
2.00)\end{array}$ & 29 & 69.05 & 4 & 8.70 \\
\hline
\end{tabular}




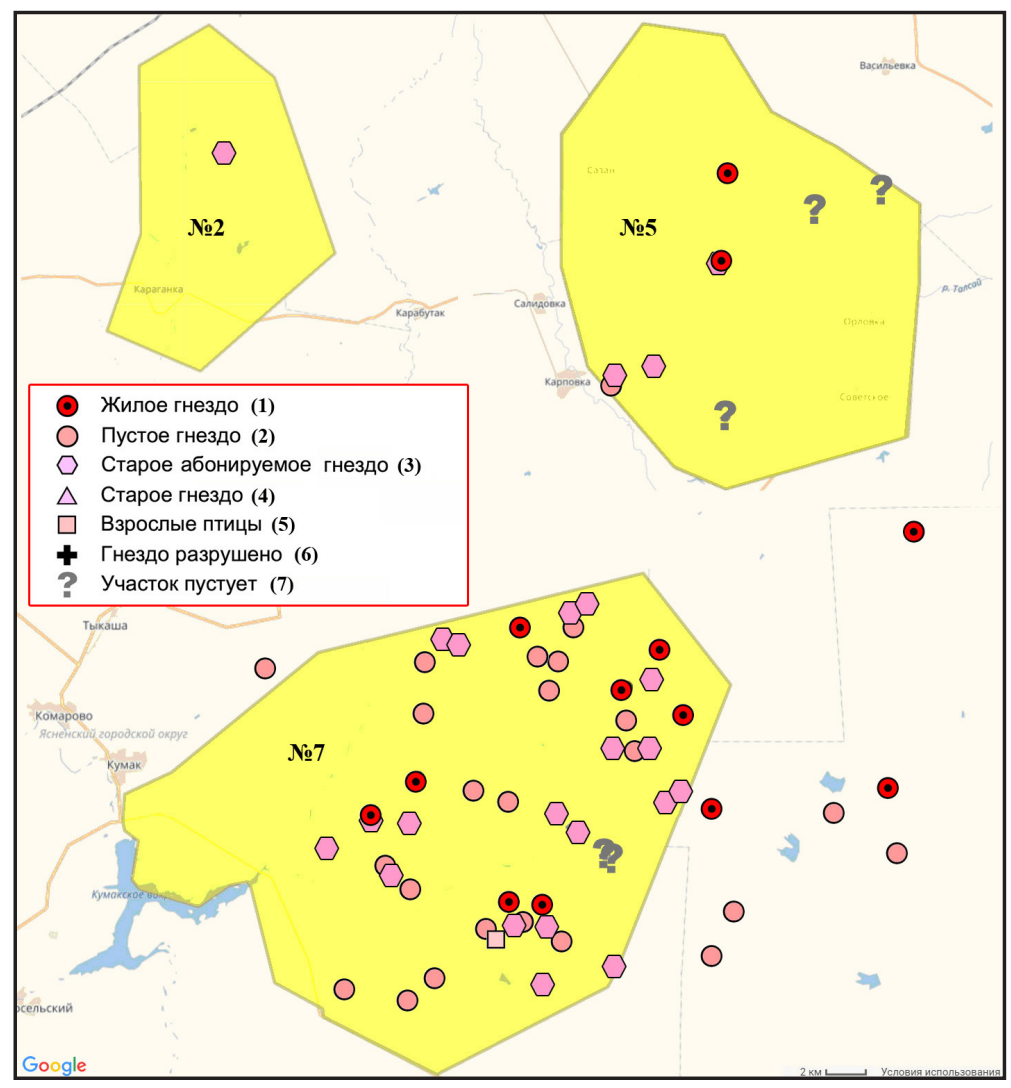

участок - около старого гнезда держалась пара птиц (рис. 5). В настояшее время Аанный гнездовой участок маркирует северный край восточной гнезАовой группировки. В связи с обшим пацением численности, зАесь остаются только спорадично гнездяшиеся пары. Плотность (по одному занятому участку) составила 0,67 пар/100 км², при отсутствии успешных гнёзА.

На площалке № 5 - Орловская степь (с 2016 г. киастер Оренбургского заповедника - «Предураиьская степь») в 2010 г. было выявлено 8 гнездовых участков, плот-

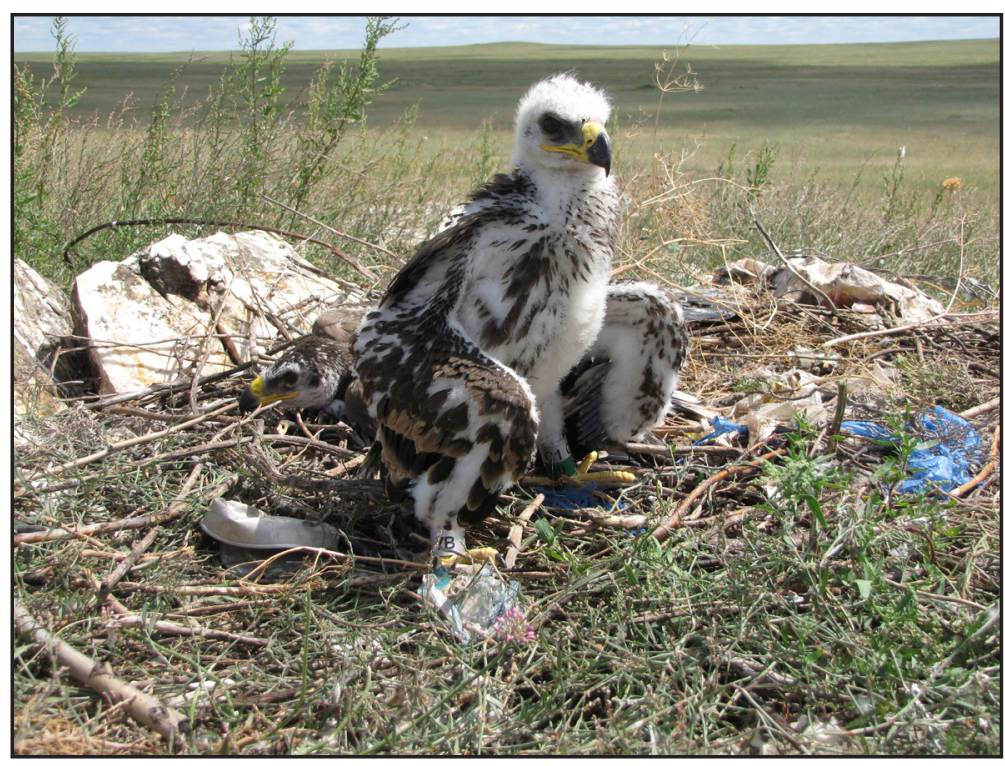

Рис. 5. Выявленные гнездовые участки степных орлов в Оренбургской области на площахках и в их окрестностях, обследованных в 2013 г. Нумерация плошацок соответствует нумерации в таблицах 1-7.

Fig. 5. Discovered breeding territories of the Steppe Eagle in the Orenburg region on the plots and in their neighborhoods surveyed in 2013. Legend: 1 - living nest (nest with clutch or brood), 2 - empty nest or nest with dead clutch or brood, 3 - old nest occupied by adult birds, 4 - old nest not occupied by adult birds, 5 - adult birds, 6 - destroyed nest, 7 - abandoned breeding territory. Numbering of plots in the figure correspond to those in tables 1-7.

ность распределения которых составила 2,17/100 км². В 2013 г. на этой площадке из 7 проверенных гнездовых территорий 4 было занято, на 2-х из которых были жимые гнезда с птенцами (рис. 5). Три гнезАовых участка степных орлов оказамись покинутыми птицами. Плотность распределения занятых гнездовых участков составила 0,75/100 км².

На площацке № 7 - Кумак-Кокпектинская - из 38 проверенных в 2013 г. гнезАовых территорий, 37 было занято, на 8 из которых были жилые гнёзда с птенцами и на 26 - пустые гнёзда со следами гибели потомства или без таковых (рис. 5), но со следами присутствия птиц, 1 участок оказаися покинутым птицами. Плотность распределения занятых гнездовых участков составила 9,37/100 км².

Средняя плотность распределения занятых гнездовых участков по трём плошацкам составила 3,89/100 км² $(1,61-9,43)$ (табл. 2). Ошибка средневзвешенной и, как следствие, несимметричный интерваи сиишком велики, из-за того, что плотность распределения гнездяшихся пар орлов на Кумак-Кокпектинской площалке

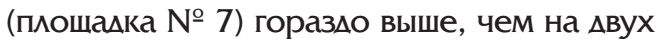
Аругих, проверенных в 2013 г. Чтобы получить более Аостоверный результат, необходим раздельный пересчёт на плошади зоны А и зоны В (см. методику и обсуждение ниже). Тем не менее, мия сравнимости результатов с исследованиями прошлых лет, гАе раздельный пересчёт не выполнями, приведём оценку численности по средней плотности распределения занятых гнездовых участков: экстраполяция на об-

Птенцы степного орла в гнезде. Фото И. Карякина.

Nestlings of the Steppe Eagle in the nest.

Photo by I. Karyakin. 
шую плошаць ареала вила в Оренбургской области (6871,5 км²) Ааёт оценку численности 267 (111-648) пар, абонируюших гнездовые участки. В 2010 г. эта оценка составляла 375 (294-479) пар, в 2012 - 289 (233-345) пар.

\section{Пиотность распределения на гнезАовании и оценка численности в 2015 году}

В 2015 г. в Оренбургской области было проверено 75 гнездовых участков степных орлов, 59 из которых (78,67 \%) осмотрено в пределах 3-х учётных плошацок, 16 (21,33 \%) - на транзитных маршрутах (рис. 6). Показатели занятости гнездовых участков приведены в таблице 3 .

На плошахке № 5 - Орловская степь из 6 проверенных гнездовых территорий 4 было занято, на 2-х из которых были жилые гнезда с птенцами и 1 безуспешно, 2 участка оказамись покинутыми птицами (рис. 6). Плотность распределения занятых гнездовых участков составила $0,75 / 100 \mathrm{KM}^{2}$.
На площадке № 6 - Малая Хобла - из 14 проверенных гнездовых территорий 7 было занято, на 4 из которых были жимые гнёзда с птенцами и 2 безуспешны, 7 участков - покинуты птицами (рис. 6). Плотность распределения занятых гнезАовых участков составила 2,48/100 км² (в 2010 г. на этой плошадке было выявлено 15 гнездовых участков (рис. 3), а плотность составила 5,31/100 км²).

На площадке № 7 - Кумак-Кокпектинская - из 39 проверенных гнездовых территорий 34 было занято, на 7 из которых были жилые гнёзда с птенцами и на 24-х гнёзда оказаяись безуспешными, 5 участков - покинуты птицами (рис. 6). Плотность распределения занятых гнездовых участков составила 8,61/100 км².

Средняя плотность распределения занятых гнездовых участков составила 3,71/100 км² $(1,72-8,04)$ - несимметричный доверительный интерваи также очень велик. Оценка численности по средней составила 255 (118-552) пар, абонируюших гнездовые участки.

Табл. 3. Показатели занятости гнездовых участков степного орла на площахках Оренбургской области в 2015 г. Нумерация плошацок соответствует нумерации на рис. 1, 3-6.

Table 3. Occupation of the Steppe Eagle breeding territories on the plots of the Orenburg region in 2015. Numbers of plots in the table correspond to those in fig. 1, 3-6.

\begin{tabular}{|c|c|c|c|c|c|c|c|c|c|c|c|c|c|}
\hline No & $\begin{array}{l}\text { Наименование } \\
\text { плошами } \\
\text { Name of plot }\end{array}$ & 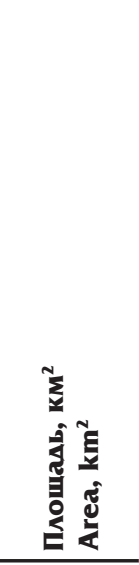 & 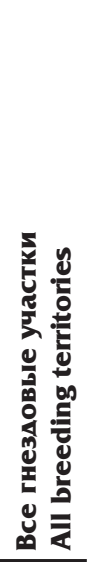 & 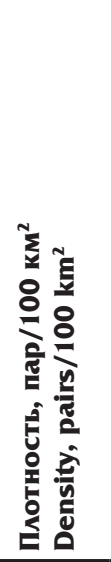 & 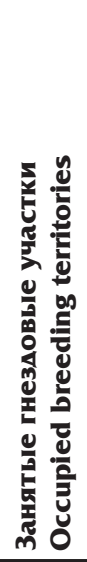 & 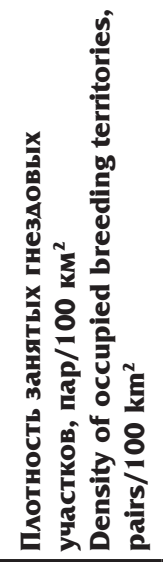 & 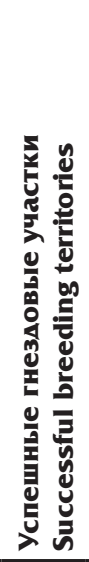 & 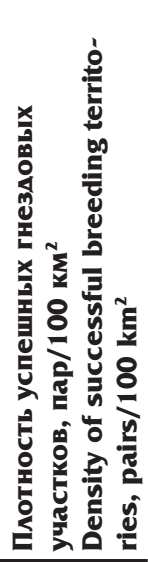 & 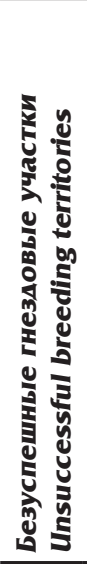 & 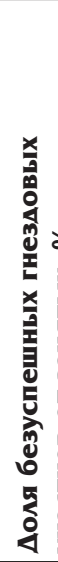 & 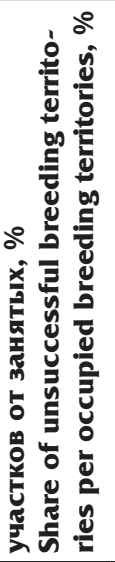 & 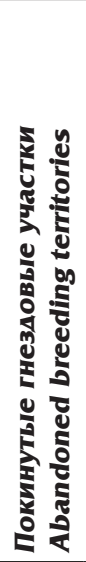 & 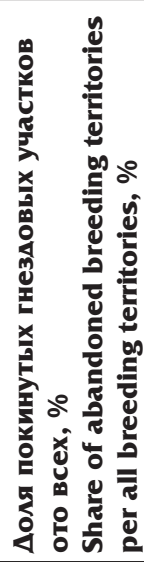 \\
\hline 5 & $\begin{array}{l}\text { Oрловская степь } \\
\text { Orkovskaya steppe }\end{array}$ & 534.91 & 6 & 1.12 & 4 & 0.75 & 2 & 0.37 & 1 & & 25.00 & 2 & 33.33 \\
\hline \multirow[t]{2}{*}{6} & $\begin{array}{l}\text { Малая Хобла } \\
\text { Malaya Hobda }\end{array}$ & 282.35 & 14 & 4.96 & 7 & 2.48 & 4 & 1.42 & 2 & & 28.57 & 7 & 50.00 \\
\hline & $\begin{array}{l}\text { Bcero / Cрецнеe } \\
\text { Total / Average }\end{array}$ & 817.26 & 20 & $\begin{array}{r}2.45 \\
(1.10- \\
5.44)\end{array}$ & 11 & $\begin{array}{r}1.35 \\
(0.67- \\
2.70)\end{array}$ & 6 & $\begin{array}{r}0.73 \\
(0.35- \\
1.55)\end{array}$ & 3 & & 27.27 & 9 & 0.45 \\
\hline \multirow[t]{2}{*}{7} & $\begin{array}{l}\text { Кумак-Кокпектинская } \\
\text { Kumak - Kokpekty }\end{array}$ & 394.74 & 39 & 9.88 & 34 & 8.61 & 7 & 1.77 & 24 & & 70.59 & 5 & 12.82 \\
\hline & $\begin{array}{l}\text { Всего / Среднее } \\
\text { (несимметричный } \\
\text { доверительный } \\
\text { интервал) } \\
\text { Total / Average } \\
\text { (asymmetric confi- } \\
\text { dence interval) }\end{array}$ & 1212.00 & 59 & $\begin{array}{r}4.87 \\
(2.43- \\
9.75)\end{array}$ & 45 & $\begin{array}{r}3.71 \\
(1.72- \\
8.04)\end{array}$ & 13 & $\begin{array}{r}1.07 \\
(0.61- \\
1.90)\end{array}$ & 27 & & 60.00 & 14 & 23.73 \\
\hline
\end{tabular}




\section{Параметры распределения гнездящихся пар в гнезАопригодных местообитаниях}

Аистанция межАу ближайшими соседями мия занятых гнёзд в 2012 г. составила в среднем $(n=32) \quad 2,93 \pm 1,99$ км $(0,76-$ 8,63 км), Амя успешных гнёзд - $(n=13)$ 2,78 $\pm 1,15$ км (0,93-4,87 км), в 2013 г. - $(n=35) 2,58 \pm 2,26 \mathrm{KM}(0,93-11,74 \mathrm{kM})$ и $(n=9)$ 4,94 $\pm 3,26$ км $(0,46-11,74$ км $)$, в 2015 г. - $(n=35) 2,86 \pm 2,53$ км $(0,82-$ 11,90 км) и $(n=12) 6,25 \pm 3,73$ км $(2,07-$ 13,07 км) соответственно.

При сохранении структуры распределения занятых гнездовых участков, тяготеюших к нормаиьному распределению с некоторым левосторонним сАвигом, в структуре распределения успешных участков происходят постоянные изменения, связанные преимушественно с гибелью гнёзд в пожарах и по причине гибели одного из партнёров (рис. 7). При этом очевиден факт распада плотных группировок и увеличения Аистанции между успешными гнёздами с 2,5-2,9 км в 2012-2013 гг. Ао 6,2 км в 2015 г. также увеличились и кратчайшие Аистанции между успешными гнёздами - с 0,76-0,93 км в 2012-2013 гг. $\Delta$ о 2,07 км в 2015 г.

\section{Численность холостьх птиц}

Устойчивость популяции определяет не только плотность распределения гнездя-

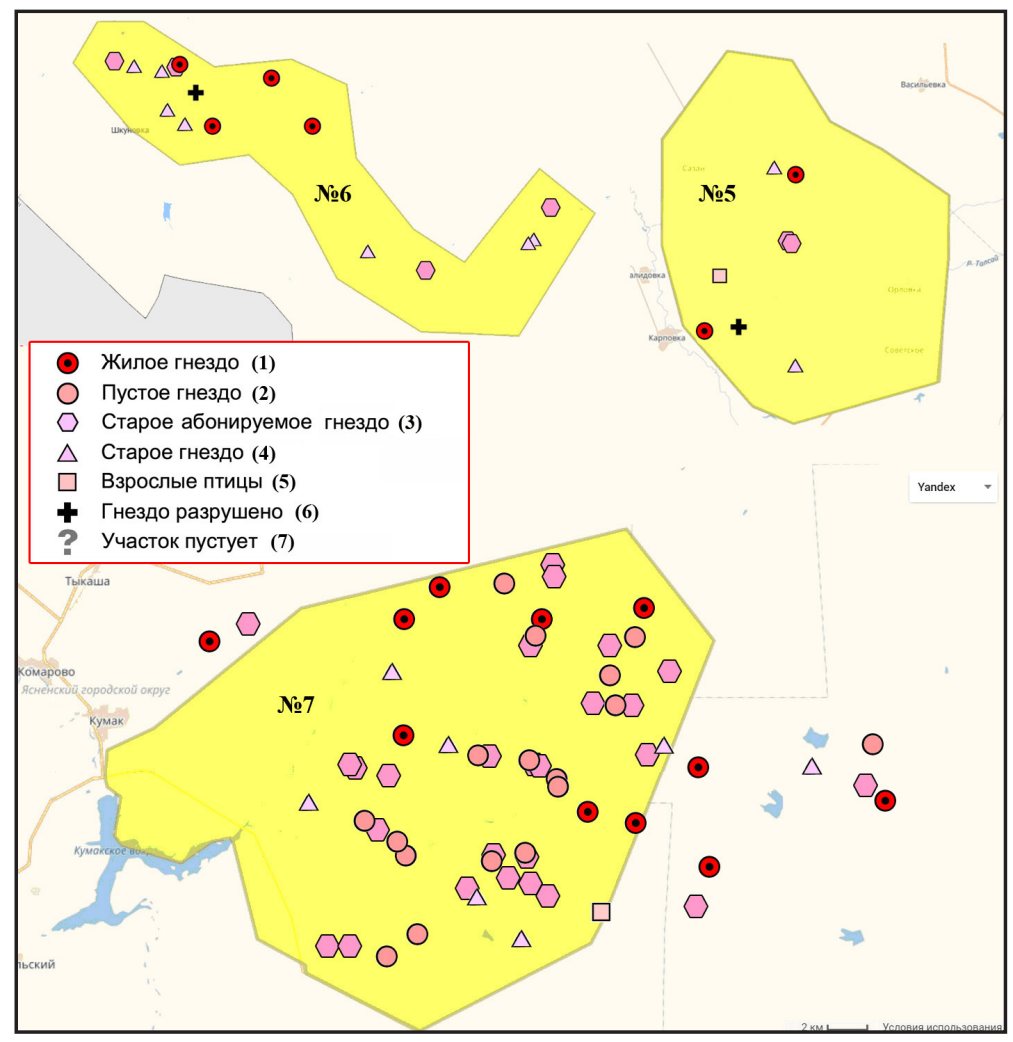

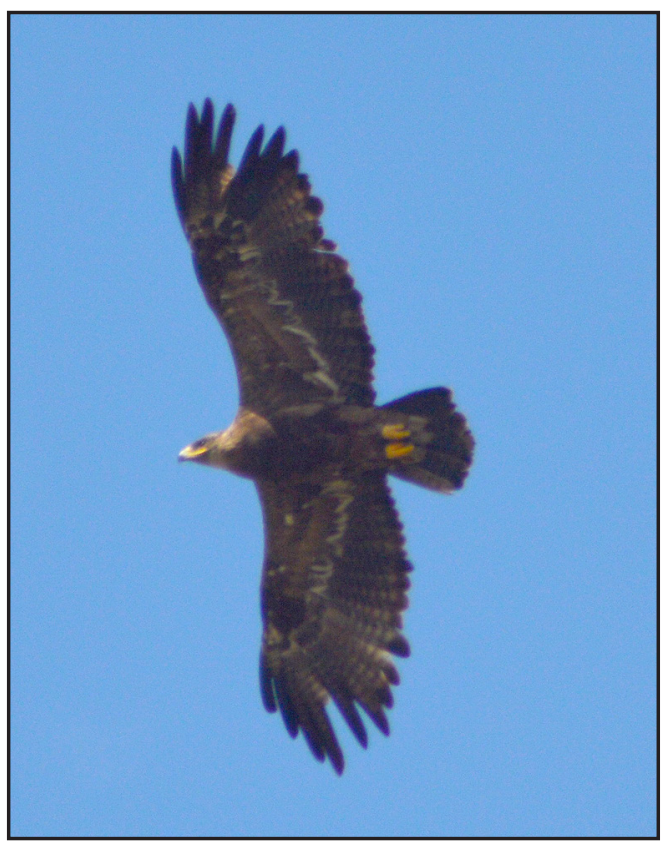

Степной орёл. Фото И. Карякина. Steppe Eagle. Photo by I. Karyakin.

шихся птиц в гнездовых биотопах, но и численность молодых неразмножаюшихся птиц, составляюших резерв популяции. Такие птицы регистрировамись нами как на плошацках, так и на маршрутах между ними.

В 2013 г. было встречено 28 птиц не привязанных к участкам в возрасте от 1 года до 4 лет, в том числе 5, 6 и 9 птиц в скоплениях близ прудов в бассейне Кумака. На площацках было встречено 22 птицы и 6 птиц на транзитных маршрутах между площадками. Обилие встреченных холостых орлов составляет 2,25 особей/100 км маршрута, в том числе на плошахках - 6,51 особей/100 км маршрута и на транзитных маршрутах между плошадками - 0,66 особей/100 км маршрута (рис. 8).

Средняя Аальность наблюдения холостых орлов в 2013 г. составила $(n=28) 0,8 \pm 0,54$

Рис. 6. Выявленные гнездовые участки степных орлов в Оренбургской области на площалках и в их окрестностях, обслецованных в 2015 г. Нумерация пмощацок соответствует нумерации в таблицах 1-7.

Fig. 6. Discovered breeding territories of the Steppe Eagle in the Orenburg region on the plots and in their neighborhoods surveyed in 2015. Legend: 1 - living nest (nest with clutch or brood), 2 - empty nest or nest with dead clutch or brood, 3 - old nest occupied by adult birds, 4 - old nest not occupied by adult birds, 5 - adult birds, 6 - destroyed nest, 7 - abandoned breeding territory. Numbering of plots in the figure correspond to those in tables 1-7. 

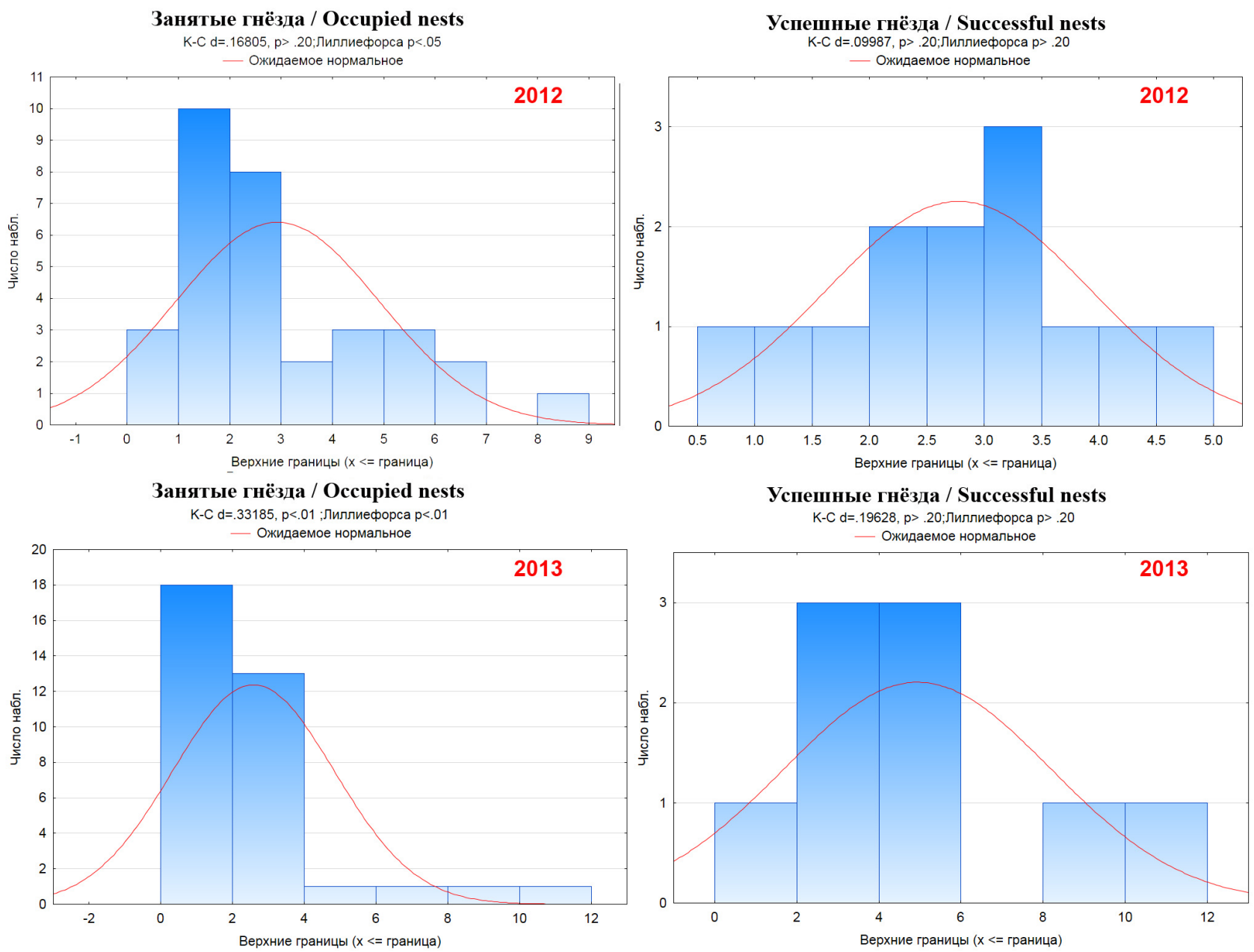

Занятые гнёзда / Occupied nests $\mathrm{K}-\mathrm{C} d=.29595, \mathrm{p}<.01 ;$ Лиллиефорса $\mathrm{p}<.01$
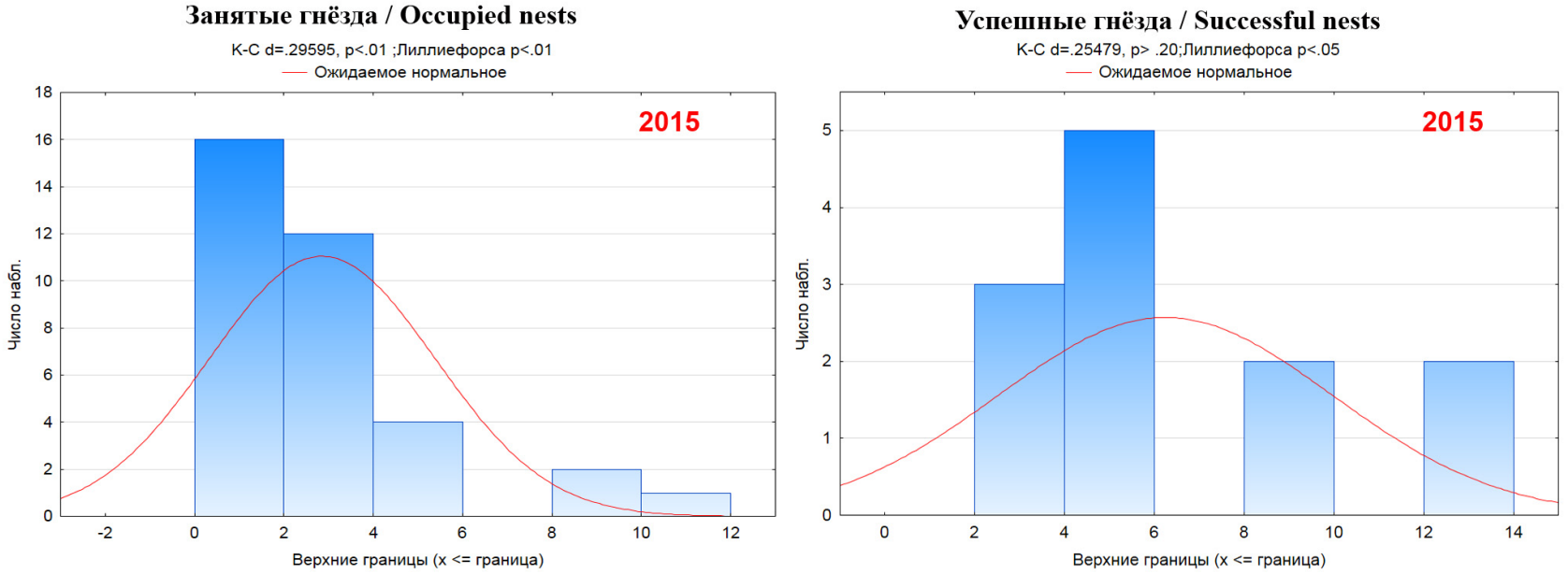

Pис. 7. Аистанции между ближайшими соседями степного орла в 2012, 2013 и 2015 гг.

Fig. 7. Distances between nearest neighbors of the Steppe Eagle in 2012, 2013 and 2015.

км (от 100 м Ао 2 км), а учётная площань 994,7 км², в том числе на площалках - 270,3 км² и за пределами плошалок - 724,5 км². Следовательно, плотность распределения холостых птиц на территории Оренбуржья в 2013 г. составляла в среднем 2,81 особей/100 км², при этом на площалках - 8,14 особей/100 км², на транзитных маршрутах - 0,83 особей/100 км².
В 2015 г. было встречено 75 холостых птиц не привязанных к участкам, причём как в возрасте от 1 года до 4 лет, так и взросмых (старше 6 лет), в том числе 11, 9, 7, 7 и 5 птиц в скоплениях в бассейне Маи. Хобды и Кумака. На плошахках было встречено 54 птицы и 21 птица на транзитных маршрутах межАу плошадками, преимушественно в Соль-Илецком, Акбулакском и Беляев- 


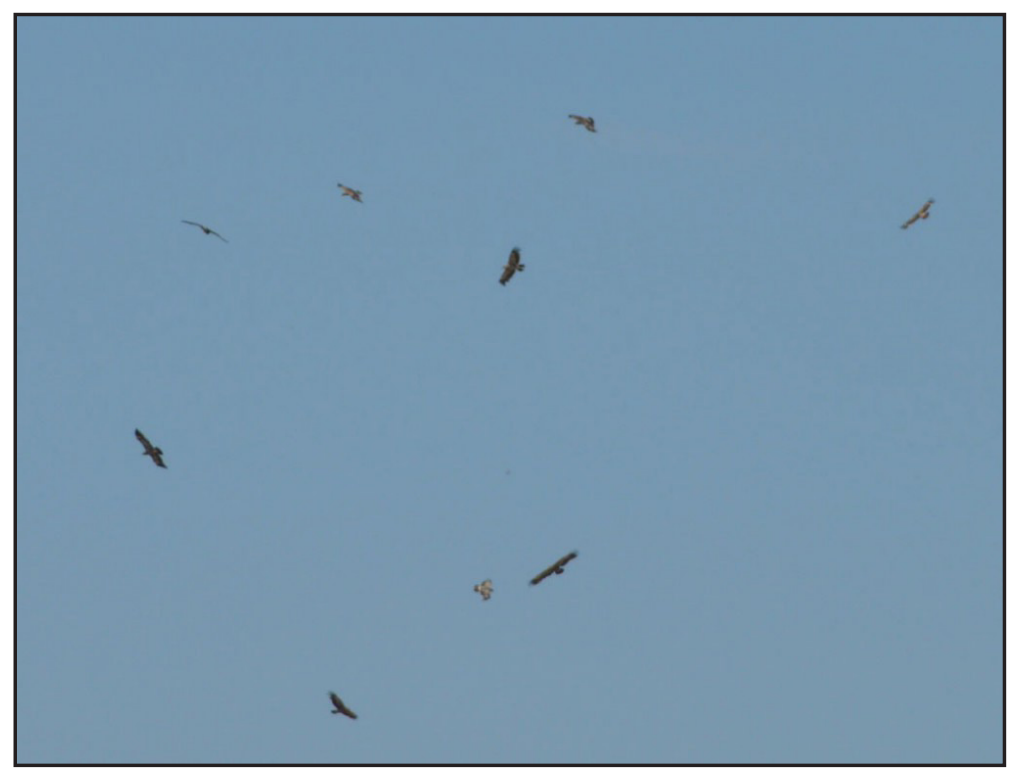

ском районах. Обилие встреченных холостых орлов составляет 4,35 особей/100 км маршрута, в том числе на плошанках - 7,45 особей/100 км маршрута и на транзитных маршрутах между плошадками - 2,10 особей/100 км маршрута (рис. 8).

Средняя Аальность наблюдения холостых орлов в 2015 г. была больше, чем в 2013 г. за счёт обнаружения скоплений из 11, 9 и 7 птиц в верховьях Малой Хоблы на дистанции 1,5 км, и составика $(n=75) 1,15 \pm 0,53$ км (от 100 м $\Delta$ о 2 км), а учётная плошань 1978,7 км², в том числе на плошалках - 832,2 км² и за пределами плошалок - 1146,5 км². СлеАовательно, плотность распределения холостых птиц на территории Оренбуржья в 2015 г. составляла в среднем 3,79 особей/100 км², при этом на плошалках - 6,49 особей/100 км², на транзитных маршрутах - 1,83 особей/100 км².

Оренбургская область лежит на северной границе распространения степного

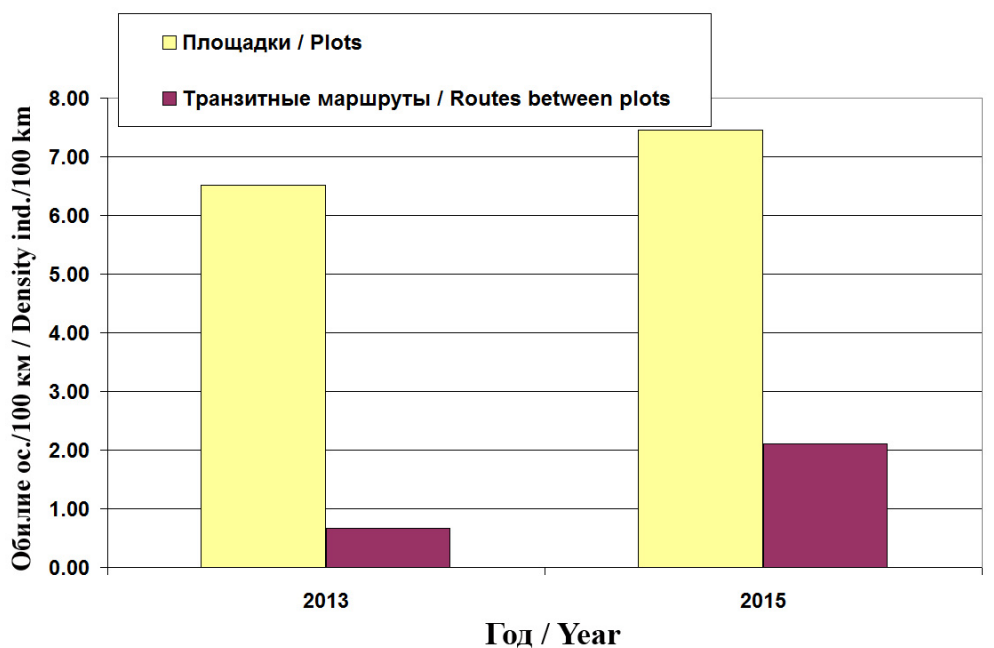

Скопление холостых степных орлов. Фото И. Карякина.

Concentration of non breeding Steppe Eagles. Photo by I. Karyakin.

орла и характеризуется достаточно плохой и неустойчивой ситуацией с малым сусликом (Spermophilus pygmaeus), который является основным объектом питания степного орла на большей территории запанной части ареала. Возможно, по этой причине Оренбуржье никогАа не являлось местом концентрации холостых птиц, как это характерно мия Волгограхского Приэльтонья на юге России, Аралсора и низовьев Узеней, южного борта Подуральского плато, бассейна Эмбы или верховьев Ори в Запанном Казахстане, гАе показатели обилия холостых птиц в 10-40 особей/100 км маршрутов мия июня - июля являются нормальным явлением, как и скопления из 30-40 особей близ степных прудов или артезианов (см. например Карякин, 2015).

Низкая встречаемость холостых птиц на транзитных маршрутах говорит как об их недоучёте, так и о том, что всё же большая часть холостых птиц реально скапливается на плошадках - т.е. там, где сохраняются гнездовые группировки степного орла, а значит, сушествуют оптимаиьные кормовые условия. Косвенным доказательством этому может служить отсутствие такой разницы во встречаемости на плошадках и транзитных маршрутах близкого вида орла-могильника (Aquila heliaca), хотя его численность в степной зоне Оренбуржья в 6 раз ниже таковой степного орла.

Обрашает на себя внимание и тот факт, что число холостых птиц в Оренбуржье в 2015 г. было сушественно выше, чем в 2013 г., что, возможно, связано с ухудшившейся кормовой ситуацией в Казахстане в 2014-2015 гг., гле трахиционно проводят лето холостые степные орлы, что и вызвало их перемешение в более северные районы. Нацо отметить, что в этот же год мы наблюдали увеличение

Рис. 8. Обилие холостых птиц в Оренбургской обмасти в 2013 и 2015 гг.

Fig. 8. Density of the non breeding birds in the Orenburg region in 2013 and 2015. 
числа молодых птиц в восстановившихся парах (см. ниже), часть из которых успешно размножаяась. Возможно, что подцержка оренбургской популяции орлов осушествляется как раз за счёт таких "выбросов" холостых особей на север в годы С низкой численностью кормов в более южных районах Казахстана.

\section{Возрастной состав размножаюшихся птиц}

В 2015 г. на гнездовых участках возраст удалось определить у 18 взрослых птиц, из которых моложе 5 лет было 8 птиц. Аоля молодых партнёров в размножаюшихся парах составила $44,4 \%$.

В 2012 г. возраст был определён у 23 взрослых птиц в гнездяшихся парах и пар- тнёров в возрасте миамше 5 лет в них было всего 5 ими $21,7 \%$, т.е. фактически в 2 раза меньше, чем в 2015 г.

Следует заметить, что мия всей трансграничной зоны России и Казахстана в 2012 г. доля молодых в размножаюшихся парах составила 49,2 \% (Карякин и мр., 2013).

\section{Выводки и эффективность размножения}

Анализ (табл. 4, 5) указывает на то, что сокрашение популяции коррелирует со снижением показателей успешности размножения: каждый год степная территория проходится пожарами именно в гнезАовой период - во все годы исследований отмечами сгоревшие гнёзда, в т.ч. с киалками и выводками.

Tабл. 4. Показатели размножения степного орла на плошацках Оренбургской области в 2013 г.

Table 4. Parameters of the Steppe Eagle reproduction on the plots of the Orenburg region in 2013.

\begin{tabular}{|c|c|c|c|c|c|c|c|c|}
\hline \multirow[b]{2}{*}{$\begin{array}{l}\text { No } \\
\mathbf{n} / \mathbf{n}\end{array}$} & \multirow[b]{2}{*}{$\begin{array}{l}\text { Наименование } \\
\text { плошамки } \\
\text { Name of plot }\end{array}$} & \multirow[b]{2}{*}{ 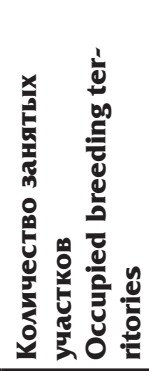 } & \multirow{2}{*}{ 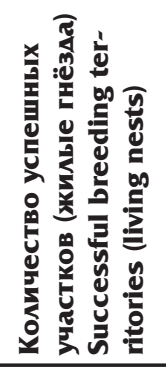 } & \multirow{2}{*}{ 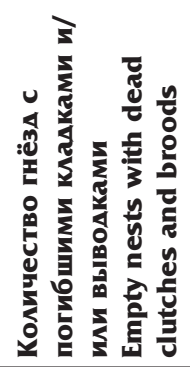 } & \multirow[b]{2}{*}{ 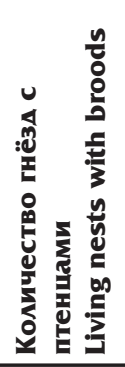 } & \multirow[b]{2}{*}{ 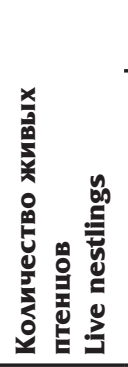 } & \multicolumn{2}{|c|}{$\begin{array}{r}\text { Успех размножения } \\
\text { Breeding success }\end{array}$} \\
\hline & & & & & & & 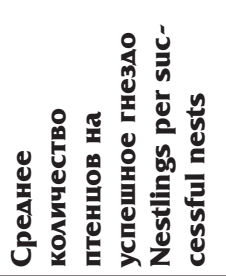 & 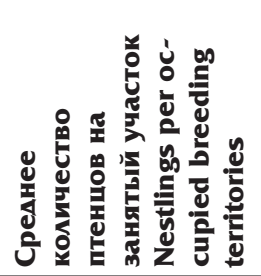 \\
\hline 5 & $\begin{array}{l}\text { Oрловская степь } \\
\text { Orkovskaya steppe }\end{array}$ & 3 & 2 & 1 & 2 & 3 & $\begin{array}{r}1.50 \pm 0.71 \\
(1-2)\end{array}$ & $\begin{array}{r}1.00 \pm 1.00 \\
(0-2)\end{array}$ \\
\hline 7 & $\begin{array}{l}\text { Кумак- } \\
\text { Кокпектинская } \\
\text { Kumak - Kokpekty }\end{array}$ & 37 & 8 & 4 & 8 & 19 & $\begin{array}{r}2.38 \pm 0.74 \\
(1-3)\end{array}$ & $\begin{array}{r}0.51 \pm 1.04 \\
(0-3)\end{array}$ \\
\hline & $\begin{array}{l}\text { Bcero/Cреднеe } \pm \text { SD } \\
\text { Total / Average } \pm \text { SD }\end{array}$ & 40 & 10 & 5 & 10 & 22 & $\begin{array}{r}2.20 \pm 0.79 \\
(1-3)\end{array}$ & $\begin{array}{r}0.55 \pm 1.04 \\
(0-3)\end{array}$ \\
\hline
\end{tabular}

Табл. 5. Показатели размножения степного орла на площахках Оренбургской области в 2015 г.

Table 5. Parameters of the Steppe Eagle reproduction on the plots of the Orenburg region in 2015.

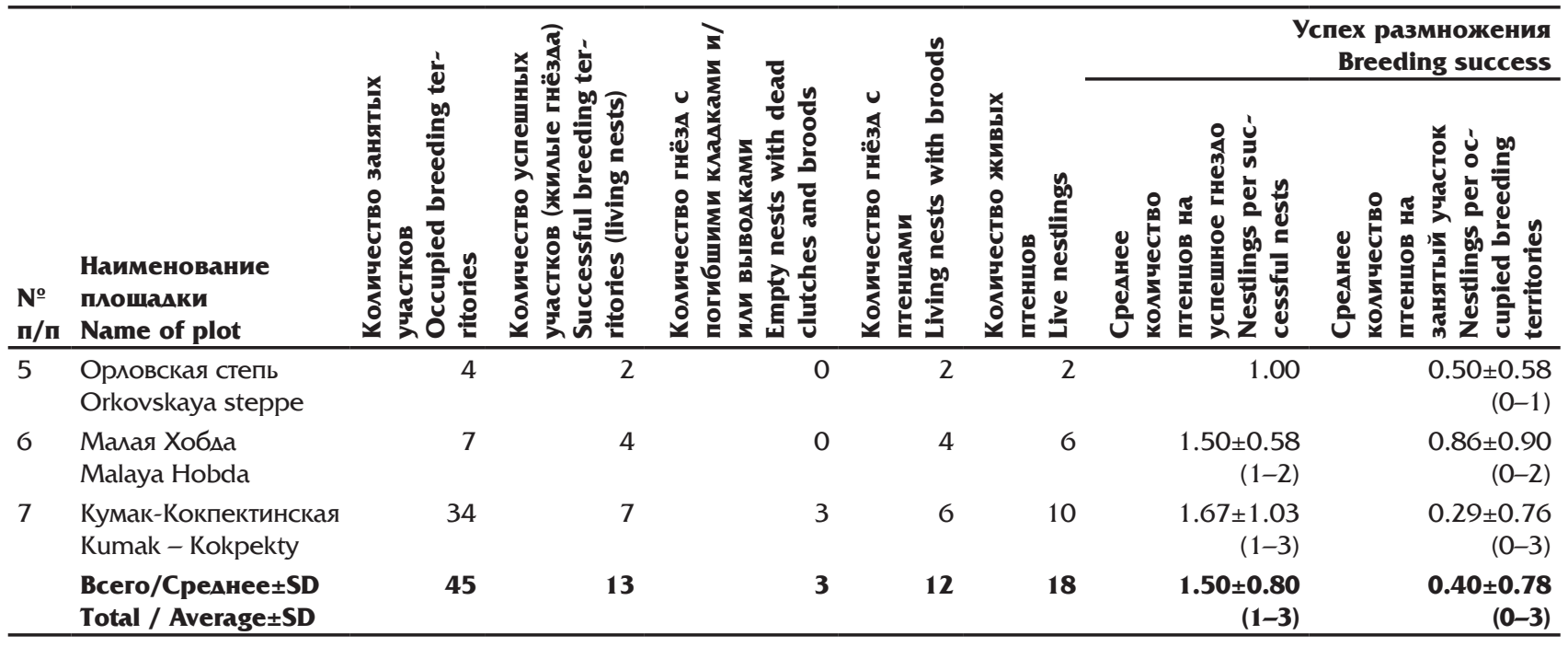



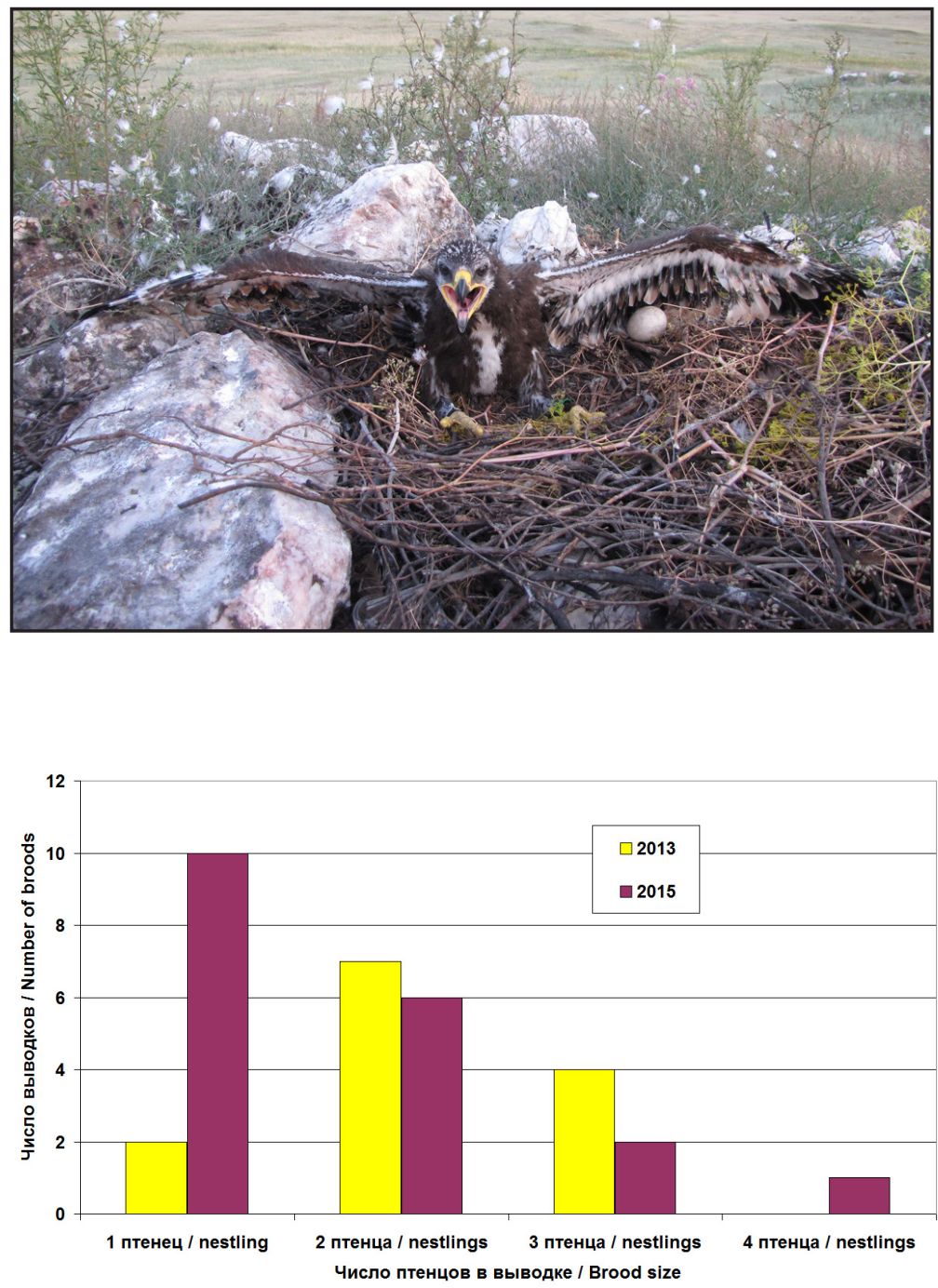

Рис. 9. Размер выводков степного орла в Оренбургской области в 2013 и 2015 гг. Fig. 9. Brood sizes of the Steppe Eagle in the Orenburg region in 2013 and 2015.

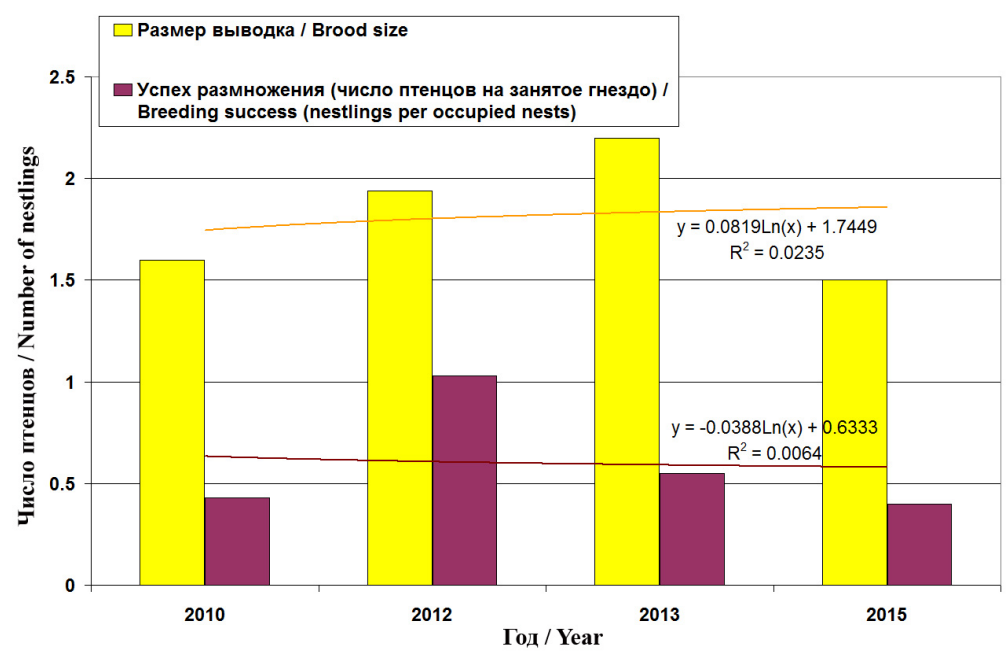

Рис. 10. Продуктивность и успешность размножения степных орлов в Оренбургской области в 2010-2015 гг.

Fig. 10. Brood sizes and breeding success of the Steppe Eagle in the Orenburg region in 2010-2015.
ОАин птенец в гнезде степного орла - частая ситуация в Оренбуржье. Фото И. Карякина.

One nestling in the nest of the Steppe Eagle is a frequent situation in the Orenburg region. Photo by I. Karyakin.

В 2010 г. в 10 гнёздах с оперёнными птенцами было от 1 Ао 2 птенцов, в среднем 1,6 0,52 птенца на успешное гнезАо или $(n=37)$ 0,43 $\pm 0,77$ птенцов на занятое гнездо. Явно Аоминировали выводки с Авумя птенцами - 60,0 \%. В одном гнезАе Аостоверно погиб выводок и 8 гнёзд сгорело во время палов, вероятно также с клахками или птенцами (Карякин и $р$., 2010).

В 2012 г. число птенцов в выводках на момент вылета варьировамо от 1 мо 3, составив в среднем $(n=18) 1,94 \pm 0,80$ птенцов на Успешное гнезАо и $(n=34) 1,03 \pm 1,14$ птенцов на занятое гнездо (Карякин и др., 2013).

В 2013 г. на плошадках из 40 занятых гнездовых участков на момент проверки жилые гнёзаа были только на 10 , количество птенцов в выводках варьирова^о от 1 Ао 3, составляя в среднем $(n=22)$ $2,20 \pm 0,79$ птенцов на успешное гнездо и ( $n=40)$ 0,55 1 1,04 птенцов на занятый гнезАовой участок. На всей обследованной территории число птенцов в выводках варьировало от 1 Ао 3, составляя в среднем $(n=28) \quad 2,15 \pm 0,69$ птенцов на успешное гнезАо (рис. 9).

В 2015 г. ситуация была похожая: из 45 занятых гнездовых участков на плошалках жилые гнёзда были только на 13 , на 12 - с птенцами, на двух были киалки (очень поздние, т.к. проверка шла в начале июля). Количество птенцов в выводках на плошалках варьировало от 1 до 3, составмяя в среднем $(n=18) 1,50 \pm 0,80$ птенца на успешное гнезАо и $(n=45)$ 0,40 $\pm 0,78$ птенцов на занятый гнезАовой участок. На всей обследованной территории число птенцов в выводках варьировало от 1 до 4, составмяя в среднем $(n=32) 1,68 \pm 0,89$ птенцов на успешное гнездо (рис. 9). Выводок из 4 птенцов в Оренбуржье был обнаружен впервые!

Сравнение показателей продуктивности и успешности размножения показывает, что в 2015 г. произошло их снижение относительно, 2012-2013 гг., однако есии сравнивать динамику с 2010 г., то кажется, что они лежат в норме фрлуктуаии (рис. 10). Тем не менее, на фоне соседнего Казахстана (см. Карякин и мр., 2013) даже лучшие показатели 2012 г. являются низ- 


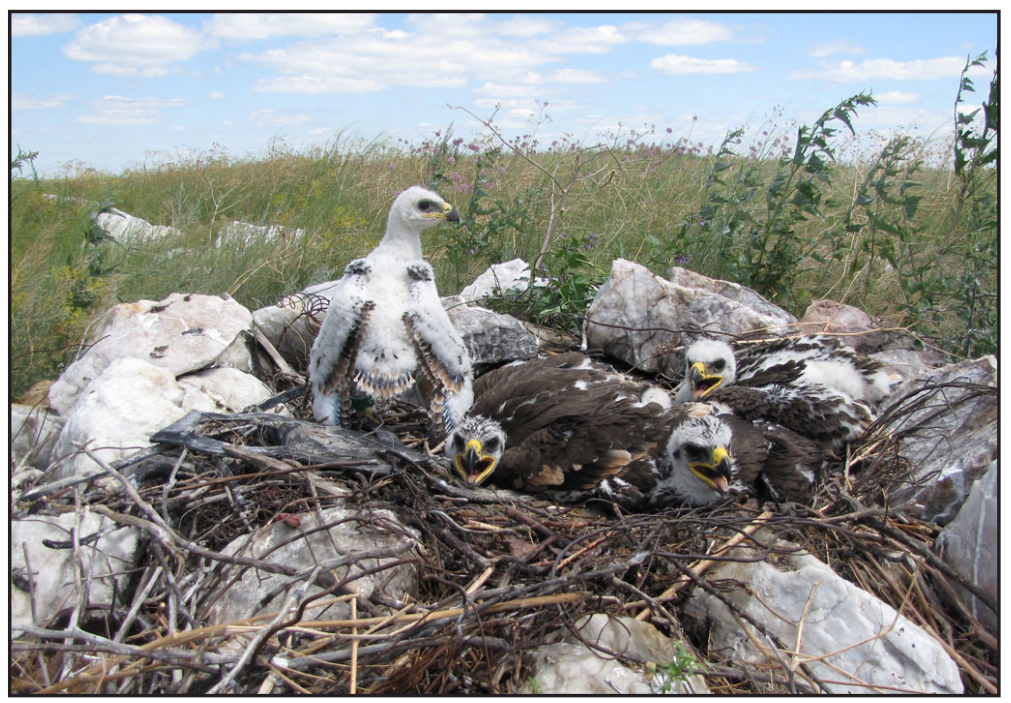

кими и имюстрируют негативную ситуацию с видом в Оренбургской области.

\section{Сравнение показателей} за годы исследований

Средняя численность степного орла в Оренбургской области снизилась за 2 года на 4,49 \%. Т.к. Аоверительный интервая слишком велик, этот результат нельзя считать налёжным, однако сравнение показателей по плошадкам, посешавшимся и в 2013 г. и 2015 г. также показывает ухудшение ситуации: на Кумак-Кокпектинской плошаАке плот-
Выводок из 4-х птенцов степного орла в Оренбургской области. Фото И. Карякина.

Four nestlings in brood of the Steppe Eagle in the Orenburg region. Photo by I. Karyakin.

ность распределения занятых гнездовых участков упала с 9,37 до 8,61 - на 8,1\%, при этом увеличилось число покинутых участков - 1 в 2013 г. и 5 в 2015 г. В Ормовской степи, казалось бы, число занятых участков осталось тем же -4 , но при этом уменьшилось обшее число участков - с 7 до 6 - покинутые в 2013 г. участки так и не восстановились.

Сравнение с Аанными 2010 и 2012 гг. (в которые делался также прямой пересчёт средней плотности на плошаць ареала) показывает дамьнейшее паление численности степного орла в Оренбургской области (табл. б). Эти Аанные можно сравнивать с некоторой "натяжкой", так как, во-первых, в 2010 г. не было обследовано самое плотное янро популяции - КумакКокпектинская плошахка, во-вторых, предполагаиось гнездование орла на площаци в 13 тыс. км², а исследование 2012 г. показа^о, что площаць ареала, на которую можно проводить экстраполяцию, практически в 2 раза ниже - 6871,5 км².

Табл. 6. Показатели плотности распределения занятых гнездовых участков степных орлов на площацках в 2010-2015 гг. и оценка численности степного орла в Оренбургской области по средней плотности распределения гнездяшихся пар.

Table 6. Density of distribution of breeding territories occupied by Steppe Eagles in plots on 2010-2015 and Steppe Eagle population numbers of in the Orenburg region at average densities of breeding pairs.

\begin{tabular}{|c|c|c|c|c|c|c|}
\hline \multirow{2}{*}{$\begin{array}{l}\text { No } \\
\mathbf{n} / \mathbf{n}\end{array}$} & \multirow{2}{*}{$\begin{array}{l}\text { Наименование площамки } \\
\text { Name of plot }\end{array}$} & \multirow{2}{*}{$\begin{array}{r}\text { Пиощамь, } \\
\mathbf{k M}^{2} \\
\text { Area, } \mathbf{k m}^{2}\end{array}$} & \multicolumn{4}{|c|}{$\begin{array}{r}\text { Плотность распределения занятых } \\
\text { гнездовых участков, пар/100 км² } \\
\text { Density of occupied breeding territories, } \\
\text { pairs } / 100 \mathrm{~km}^{2}\end{array}$} \\
\hline & & & 2010 & 2012 & 2013 & 2015 \\
\hline 1 & $\begin{array}{l}\text { Ашисайская степь } \\
\text { Aschisayskaya steppe }\end{array}$ & 441.59 & 2.95 & & & \\
\hline 2 & $\begin{array}{l}\text { Караганды (мелкосопочник нах долиной реки) } \\
\text { Karagandy }\end{array}$ & 148.89 & 2.69 & & 0.67 & \\
\hline 3 & $\begin{array}{l}\text { Айтуарская степь } \\
\text { Aytuarskaya steppe }\end{array}$ & 307.77 & 1.95 & & & \\
\hline 4 & $\begin{array}{l}\text { Буртинская степь } \\
\text { Burtinskaya steppe }\end{array}$ & 256.08 & 2.34 & & & \\
\hline 5 & $\begin{array}{l}\text { Орловская степь } \\
\text { (мелкосопочник в междуречье рр. Буртя и Уртабуртя) } \\
\text { Orkovskaya steppe }\end{array}$ & 534.91 & 2.17 & 1.12 & 0.75 & 0.75 \\
\hline 6 & $\begin{array}{l}\text { Мамая Хобда (степной массив нах долиной реки) } \\
\text { Malaya Hobda }\end{array}$ & 282.35 & 5.31 & & & 2.48 \\
\hline \multirow[t]{3}{*}{7} & $\begin{array}{l}\text { Кумак-Кокпектинская (Ясный) } \\
\text { Kumak - Kokpekty (Yasnyi) }\end{array}$ & 394.74 & & 8.36 & 9.37 & 8.61 \\
\hline & Всего / Среднеe Total / Average & 2366.33 & 2.88 & 4.20 & 3.89 & 3.71 \\
\hline & $\begin{array}{l}\text { Оценка численности по средней плотности населения, пар } \\
\text { Estimates of the population numbers on average density, pairs }\end{array}$ & & $\begin{array}{r}375 \\
(294-479)\end{array}$ & $\begin{array}{r}289 \\
(233-345)\end{array}$ & $\begin{array}{r}267 \\
(111-648)\end{array}$ & $\begin{array}{r}255 \\
(118-552)\end{array}$ \\
\hline
\end{tabular}


Аостоверную Аинамику (насколько она может быть Аостоверна при оценке по средней плотности) можно проследить по результатам 2012, 2013 и 2015 г. - пацение численности составило $11,8 \%$ за 3 года. Показатели плотности распределения гнездяшихся пар на отлельных плошалках равномерно снижаются: на площадке Малая Хобла - более чем в 2 раза, в Орловской степи - почти в 3 раза, в Аолине р. Караганды степной орёл практически исчез с 2010 г. И только янро популяции остается более-менее стабильным в 20122015 гг. - плотность занятых участков в 2013 г. тут была чуть выше, чем в 2012 г. и 2015 г.

Аанные 2010 г. можно учесть, если взять показатели на тех плошадках, которые проверялись повторно в 2013 г. и/ или 2015 г., Аобавив результат по КумакКокпектинской плошацке, полученный в 2012 г. (предполагая, что в 2010 г. ситуация на ней была не хуже) и экстраполировав среднюю плотность на уточненную площадь гнезАопригодных местообитаний - 6871,5 км². Оцененная таким образом численность составляет 321 (196-525) пар (табл. 7). Считая эту оценку более достоверной, получаем пацение численности степного орла за 5 лет на 20,6 \% - с 321 (196-525) до 255 (118-552) пар.

Необходимо также обратить внимание, что сравнивая результаты 2015 г. с 2013 и 2012 нало учитывать, что в 2015 г. была осмотрена плошадка № 6 "Маяая Хобла", плотность орлов на которой более чем в 2 раза выше, чем в Орловской степи и в долине р. Караганды. Корректным мия понимания Аинамики вида является сравнение результатов 2015 г. с 2010 г. (по зоне B, см. рис. 2), а также анализ изменения Аанных по годам на каждой плошалке в отдельности - на трёх таких плошадках в зоне В плотность гнездования упаяа за 5 лет в 2-4 раза.

ия более точной оценки численности степного орла был выполнен раздельный пересчёт плотностей мия янра популяции (зона A) и остальной её части (зона В) (табл. 8). Чтобы полученные в 2013 и 2015 гг. Аанные можно было сравнивать с Аанными 2010 г. и 2012 г. Аанные этих лет также экстраполироваяи раздельно на зоны А и В.

Анамиз таблицы 8 показывает, что около 80 \% популяции степного орла в Оренбургской области сосредоточено в "янре" - на кварцитовых грялах Заурамья (зона А),

Табл. 7. Показатели плотности распределения занятых гнездовых участков степных орлов на площадках, которые были осмотрены более одного раза за 2010-2015 гг. и оценки численности степного орла в Оренбургской области, полученные в результате экстраполяции средней плотности распределения гнездовых участков и по раздельному пересчёту на зоны А и В. Обозначение зон гнездового ареала в таблице соответствует нумерации на рис. 2.

Table 7. Density of distribution of breeding territories occupied by Steppe Eagles in plots on 2010-2015 and Steppe Eagle population numbers of in the Orenburg region calculated at the base of extrapolation of average density of breeding territory distribution and separate calculations for zones A and B. Marking of zones of the breeding range in the table correspond to those in fig. 2.

\begin{tabular}{|c|c|c|c|c|c|c|}
\hline \multirow{2}{*}{$\begin{array}{l}\mathbf{N} N \\
\mathbf{n} / \mathbf{\Pi}\end{array}$} & \multirow[b]{2}{*}{ Наименование площамки Name of plot } & \multirow{2}{*}{$\begin{array}{r}\text { Пиощамь, } \\
\text { км² Area, } \\
\text { km² }^{2}\end{array}$} & \multicolumn{4}{|c|}{$\begin{array}{r}\text { Пиотность распределения занятых } \\
\text { гнездовых участков, пар/100 км² } \\
\text { nsity of occupied breeding territories, } \\
\text { pairs } / 100 \mathrm{~km}^{2}\end{array}$} \\
\hline & & & 2010 & 2012 & 2013 & 2015 \\
\hline 2 & $\begin{array}{l}\text { Караганды (мелкосопочник нах долиной реки) } \\
\text { Karagandy }\end{array}$ & 148.89 & 2.69 & & 0.67 & \\
\hline 5 & $\begin{array}{l}\text { Орловская степь } \\
\text { (мелкосопочник в междуречье рр. Буртя и Уртабуртя) } \\
\text { Orkovskaya steppe }\end{array}$ & 534.91 & 2.17 & 1.12 & 0.75 & 0.75 \\
\hline 6 & $\begin{array}{l}\text { Мамая Хобла (степной массив нах долиной реки) } \\
\text { Malaya Hobda }\end{array}$ & 282.35 & 5.31 & & & 2.48 \\
\hline \multirow[t]{3}{*}{7} & $\begin{array}{l}\text { Кумак-Кокпектинская (Ясный) } \\
\text { Kumak - Kokpekty (Yasnyi) }\end{array}$ & 394.74 & $8.36^{*}$ & 8.36 & 9.37 & 8.61 \\
\hline & $\begin{array}{l}\text { Оценка численности по средней плотности } \\
\text { населения, пар } \\
\text { Estimates of the population numbers on average den- } \\
\text { sity, pairs }\end{array}$ & 6871.50 & $\begin{array}{r}321 \\
(196-525)\end{array}$ & $\begin{array}{r}289 \\
(233-345)\end{array}$ & $\begin{array}{r}267 \\
(111-648)\end{array}$ & $\begin{array}{r}255 \\
(118-552)\end{array}$ \\
\hline & $\begin{array}{l}\text { Раздельный пересчет на зоны А и В } \\
\text { Separate calculation for zones A and B }\end{array}$ & $\begin{array}{l}A=4103.95 \\
B=2767.55\end{array}$ & $\begin{array}{r}369 \\
(320-447)\end{array}$ & 277 & $\begin{array}{r}289 \\
(287-291)\end{array}$ & $\begin{array}{r}293 \\
(266-349)\end{array}$ \\
\hline
\end{tabular}

Примечание / Note:

* - предполагается, что в 2010 г. плотность на Кумак-Кокпектинской площадке была такая же, как в 2012 г. / assumed that the density on the Kumak-Kokpeky plot in 2010 was the same as in 2012 
Табл. 8. Оценка численности степного орла в Оренбургской области раздельным пересчётом показателей плотности распрецеления гнездяшихся пар на зоны А и В в 2010-2015 гг. Обозначение зон гнездового ареала в таблице соответствует нумерации на рис. 2.

Table 8. The Steppe Eagle numbers in the Orenburg region obtained as a result of separate calculation of density of distribution of breeding territories for zones A and B in 2010-2015. Marking of zones of the breeding range in the table correspond to those in fig. 2.

\begin{tabular}{|c|c|c|c|c|c|c|c|}
\hline $\begin{array}{l}\text { Зоны } \\
\text { гнездового } \\
\text { apeana } \\
\text { Zones of } \\
\text { the breed- } \\
\text { ing range }\end{array}$ & $\begin{array}{r}\text { Пиошамь, } \\
\text { км² }^{2} \\
\text { Area, km² }\end{array}$ & $\begin{array}{r}\text { Плотность } \\
\text { распрелеления } \\
\text { всех участков } \\
\text { на плошакках, } \\
\text { пар/100 км² } \\
\text { Density of } \\
\text { all breeding } \\
\text { territories, } \\
\text { pairs/100 km² }\end{array}$ & $\begin{array}{r}\text { Максимально } \\
\text { возможная } \\
\text { численность } \\
\text { популяции, } \\
\text { пары } \\
\text { The maxi- } \\
\text { mum possible } \\
\text { population } \\
\text { size, pairs }\end{array}$ & $\begin{array}{r}\text { Плотность } \\
\text { распределения } \\
\text { занятьх } \\
\text { участков на } \\
\text { плошамках, } \\
\text { пар/100 км² } \\
\text { Density of ос- } \\
\text { cupied breed- } \\
\text { ing territories, } \\
\text { pairs/100 km² }\end{array}$ & $\begin{array}{r}\text { Число } \\
\text { занятых } \\
\text { гнездовых } \\
\text { участков } \\
\text { Estimated } \\
\text { number of } \\
\text { occupied } \\
\text { breeding } \\
\text { territories }\end{array}$ & $\begin{array}{r}\text { Плотность } \\
\text { распределения } \\
\text { успешных } \\
\text { гнёзд на } \\
\text { площахках, } \\
\text { пар / } 100 \text { км}^{2} \\
\text { Density of suc- } \\
\text { cessful breed- } \\
\text { ing territories, } \\
\text { pairs/100 km² }\end{array}$ & $\begin{array}{r}\text { Численность } \\
\text { успешно } \\
\text { размножаюшихс } \\
\text { пар } \\
\text { Estimated num } \\
\text { ber of successfu } \\
\text { breeding pairs }\end{array}$ \\
\hline \multicolumn{8}{|c|}{2015} \\
\hline Зона A & 2767.55 & 9.88 & 273 & 8.61 & 238 & 1.77 & 49 \\
\hline Зона В & 4103.95 & $\begin{array}{r}2.45 \\
(1.10-5.44)\end{array}$ & $\begin{array}{r}100 \\
(45-223)\end{array}$ & $\begin{array}{r}1.35 \\
(0.67-2.70)\end{array}$ & $\begin{array}{r}55 \\
(28-111)\end{array}$ & $\begin{array}{r}0.73 \\
(0.35-1.55)\end{array}$ & $30(14-64)$ \\
\hline $\begin{array}{l}\text { Сумма } \\
\text { Sum }\end{array}$ & 6871.50 & & $\begin{array}{r}293 \\
(266-349) \\
\end{array}$ & & $\begin{array}{r}293 \\
(266-349) \\
\end{array}$ & & $79(63-113)$ \\
\hline \multicolumn{8}{|c|}{2013} \\
\hline Зона A & 2767.55 & 9.63 & 267 & 9.37 & 259 & 2.03 & 56 \\
\hline Зона В & 4103.95 & $\begin{array}{r}1.17 \\
(0.86-1.60)\end{array}$ & $\begin{array}{r}48 \\
(35-66)\end{array}$ & $\begin{array}{r}0.73 \\
(0.68-0.78)\end{array}$ & $\begin{array}{r}30 \\
(28-32)\end{array}$ & $\begin{array}{r}0.29 \\
(0.16-0.55)\end{array}$ & $12(6-22)$ \\
\hline $\begin{array}{l}\text { Сумма } \\
\text { Sum }\end{array}$ & 6871.50 & & $\begin{array}{r}315 \\
(302-332) \\
\end{array}$ & & $\begin{array}{r}289 \\
(287-291) \\
\end{array}$ & & $68(62-78)$ \\
\hline \multicolumn{8}{|c|}{2012} \\
\hline Зона A & 2767.55 & 9.88 & 273 & 8.36 & 231 & 4.050 & 112 \\
\hline Зона В & 4103.95 & 1.50 & 62 & 1.12 & 46 & 0.370 & 15 \\
\hline $\begin{array}{l}\text { Сумма } \\
\text { Sum }\end{array}$ & 6871.50 & & 335 & & 277 & & 127 \\
\hline \multicolumn{8}{|c|}{2010} \\
\hline Зона A & 2767.55 & & & $8.36^{*}$ & 231 & & \\
\hline Зона В & 4103.95 & & & $\begin{array}{r}3.37^{* *} \\
(2.16-5.26)\end{array}$ & $\begin{array}{r}138 \\
(89-216)\end{array}$ & & \\
\hline $\begin{array}{l}\text { Сумма } \\
\text { Sum }\end{array}$ & 6871.50 & & & & $\begin{array}{r}369 \\
(320-447)\end{array}$ & & \\
\hline
\end{tabular}

Примечание / Note:

* - предполагается, что в 2010 г. плотность на Кумак-Кокпектинской плошахке была такая же, как в 2012 г. / аssumed that the density on the Kumak-Kokpeky plot in 2010 was the same as in 2012

** - мя 2010 г. в расчёт взяты только плошалки, которые были повторно осмотрены в 2012-2015 гг. / for 2010 in the саlсulation involved only plots that have been re-surveyed in 2012-2015

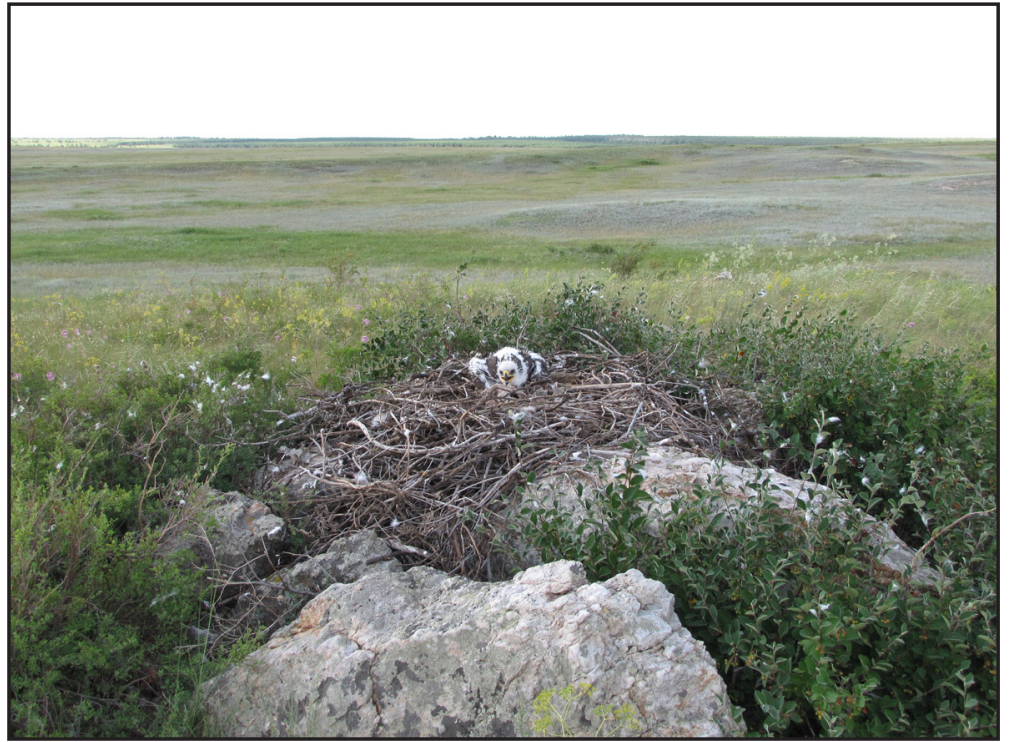

плошадь которой составляет 40,7 \% всего ареала в области, поскольку плотность распределения гнездящихся пар орлов

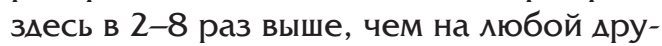
гой плошалке за все годы исследований. Поэтому колебания показателей плотности на Кумак-Кокпектинской плошалке оказывают влияние на обшую оценку численности вида, сравнимое с вкиючением или искАючением из учёта Аюбой

Самое северное активное гнездо степного орла в Ацамовском районе Оренбургской области. Фото И. Карякина.

The northernmost active nest of the Steppe Eagle in the Adamovsky District of the Orenburg region. Photo by I. Karyakin. 
Гнездо степного орла на опоре АЭП в Восточном Оренбуржье. Фото И. Карякина. Nest of the Steppe Eagle on the electric pole in the eastern part of the Orenburg region. Photo by I. Karyakin.
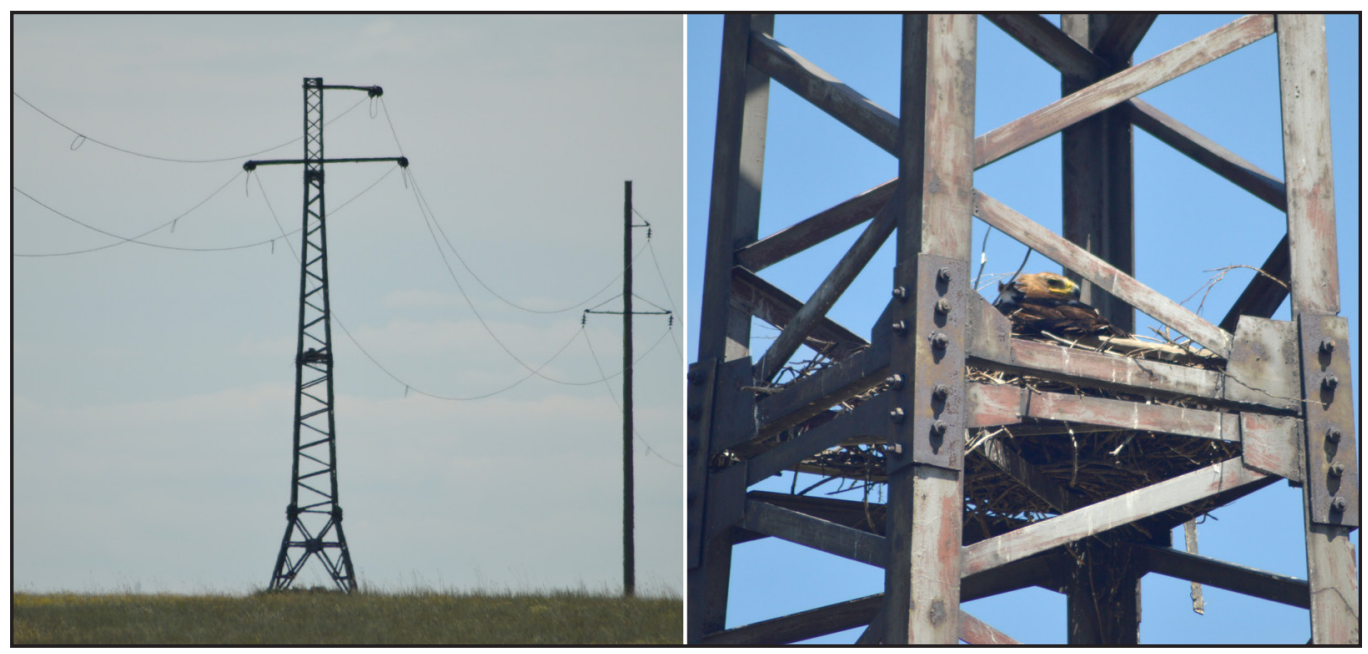

Аругой плошадки в зоне В. Так, вкАючение в 2015 г. в учёт плошахки Маяая Хоб$\Delta а$ увеличило среднюю численность степных орлов в зоне В на 25 пар - с 30 пар в 2013 г. Ао 55 пар в 2015 г., в то время как пацение плотности на Кумак-Кокпектинской площахке всего на 0,76 пар/100 км$^{2}$ за этот же период понизило обшую численность на 21 пару - тренд с 2013 по 2015 остался положительным (на 4 пары), но это никак не отражает реацьную динамику численности вида в регионе.

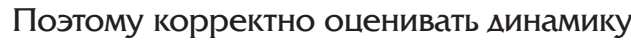
популяции, сравнивая показатели 2015 и 2010 гг., полученные раздельным пересчётом (табл. 7). Отрицательный тренд составляет 20,6 \%, несмотря на устойчивую ситуацию на плошалке в "ялре" популяции (с оговоркой, что реально мы не знаем тут ситуацию в 2010 г.). Темп сокрашения численности близок к таковому, оцененному за 2006-2012 гг., который составлял $-18,75 \%$

Пацение плотности гнездования орлов на площадках в зоне В показывает, что по-

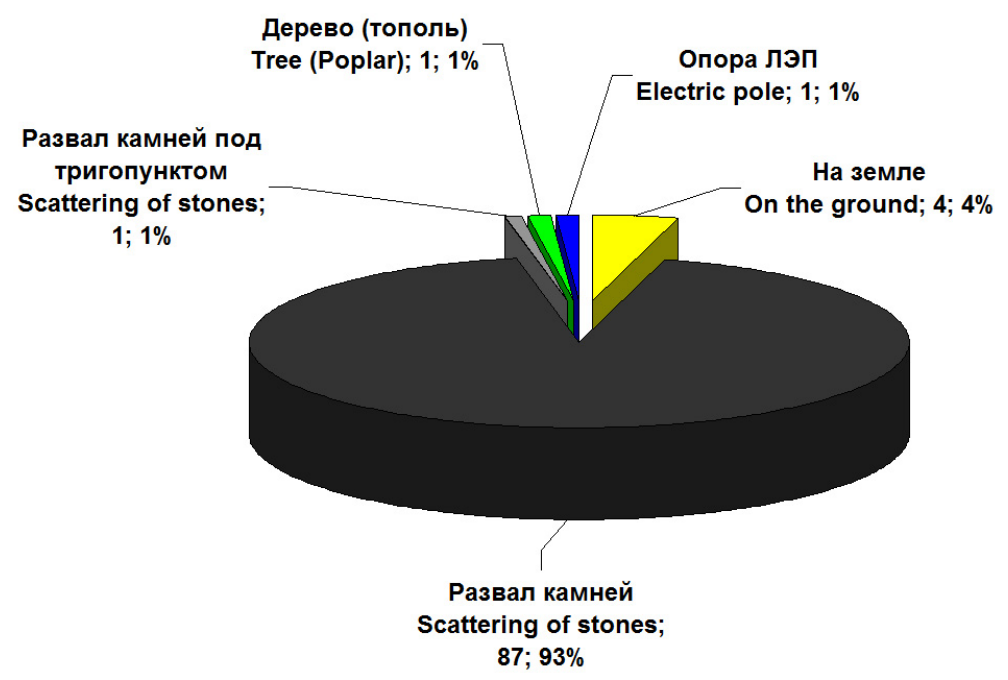

пуляция "тает" на перисерии, при том, что её ялро пока Аостаточно устойчиво. Однако, мы не можем утверждать, что одинаково высокая плотность сохраняется во всей зоне А, вероятно, на краях также илёт сокрашение, за 3 последних года не коснувшееся территории Кумак-Кокпектинской площаАки.

Очевидным фактом ухудшения ситуации является омоложение гнезАовой группировки на фоне сокрашения численности, что мы наблюдаем, сравнивая возраст птиц в размножаюшихся парах и динамику занятости гнездовых участков в 2012 и 2015 гг., в основном как раз по Кумак-Кокпектинской плошанке.

\section{Особенности гнездования}

В Оренбургской области степной орёл типичный наземногнездяшийся вид. 3Аесь Ао сих пор не наблюдается какой-либо серьёзной ацаптации птиц к освоению Аля гнездования АЭП или деревьев.

Если на юго-запале области степной орёл гнездится в основном по степным возвышенностям речных Аолин, то на востоке преимушественно в ровной степи на выходах кварцитов. В центраиьной части области наблюдалось гнездование на полноценных скамьных обнажениях, но в настояшее время в местообитаниях с настояшими скалами (Губерля, отроги Южного Урама) вин попросту исчез.

На востоке Оренбургской области первое гнездо степного орла на метамической опоре ^ЭП и попытка гнездования

Рис. 11. Места устройства гнёзд степного орла в Оренбургской области.

Fig. 11. The nest locations of the Steppe Eagle in the Orenburg region. 


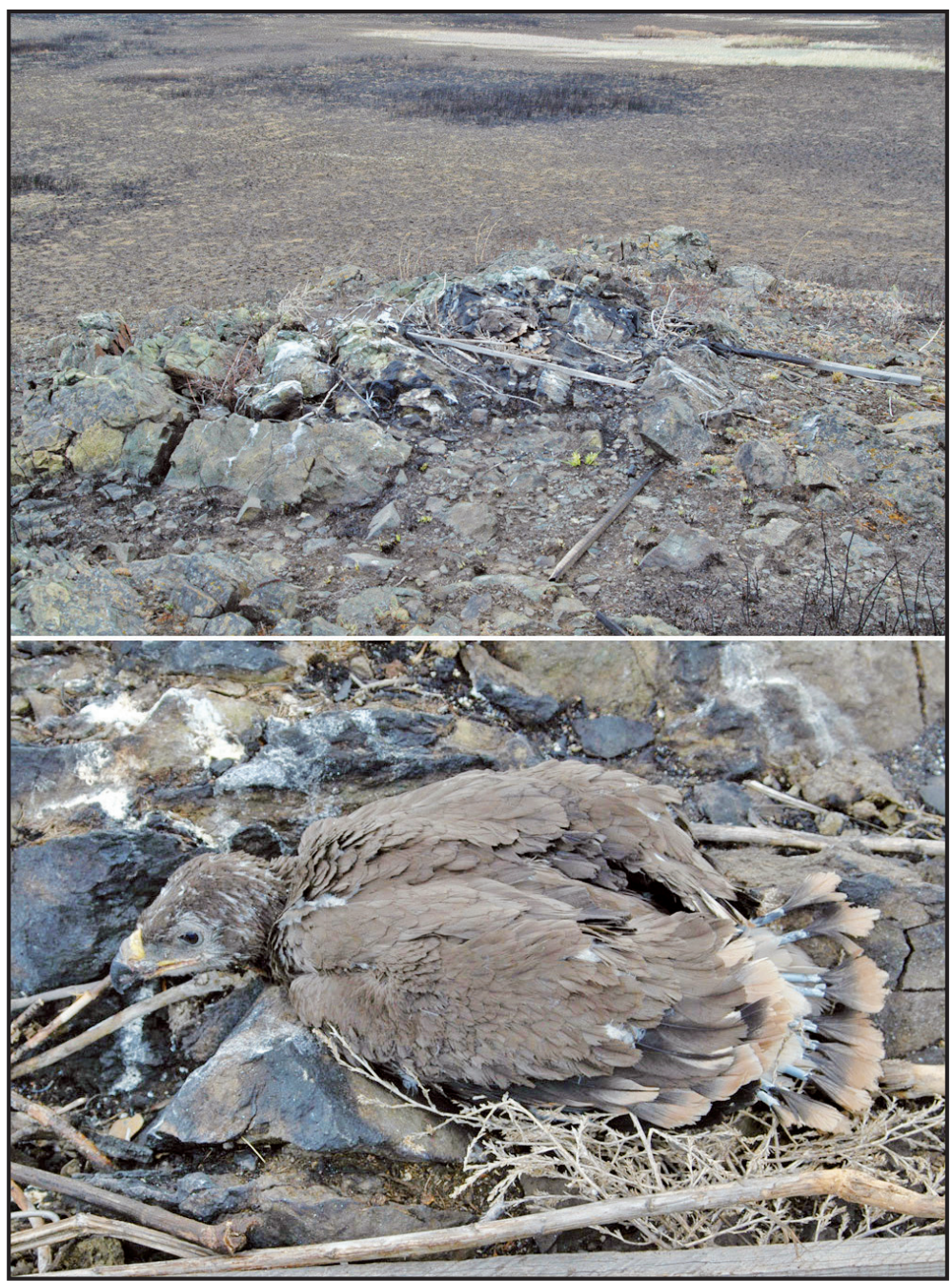

на дереве выявлены в 2015 г. (рис. 11), причём на многолетних гнездовых участках, на которых гнёзда орлов сгораяи 2 года подрял. Пока неясно, закрепится ки подобный стереотип гнездования, но то что он уже появился, имеет определённые перспективы.

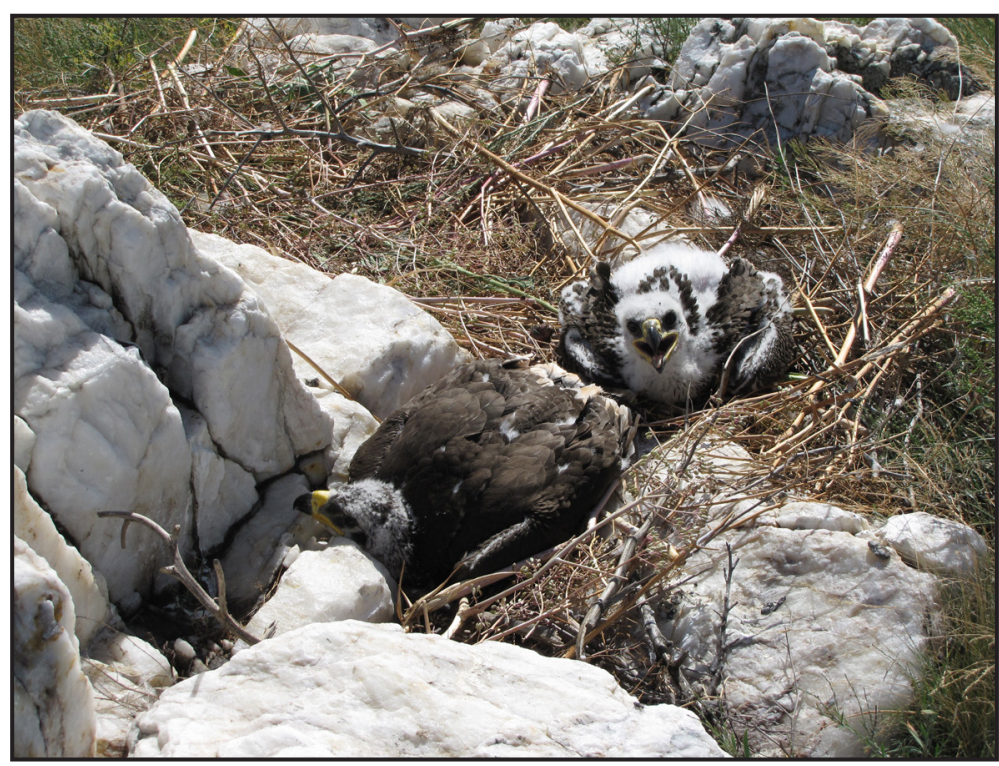

Гнездо степного орла в Акжарской степи, пройденное пожаром - один птенец погиб, второй выжил, но выпуску в природу не подеежит. Фото И. Карякина.

Steppe Eagle's nest in the burnt Akzhar steppe - a nestling is died and another nestling survived, but the release in nature is not possible. Photo by I. Karyakin.

\section{Угрозы и лимитирующие факторы}

Степной орёл сушественно зависит от обилия роюших грызунов и, в первую очередь, малого суслика. Аинамика численности этого грызуна во многом определяет динамику численности степного орла. ОАнако в условиях Оренбургской области эта зависимость не такая яркая, как например, в полупустынных районах Западного Казахстана и российской части Прикаспия. В последние годы на фоне затяжной депрессии численности малого суслика степные орлы питаются преимушественно большими сусликами (Spermoplilus major), полёвками (Microtus sp.) и различными степными птицами. Анализ динамики рациона степного орла в Оренбуржье за последние десятилетия - это тема отдельной статьи. 3Аесь же хочется отметить, что в условиях Оренбуржья в настояшее время кимит кормов не является фактором, определяюшим сокрашение численности, хотя он оказывает сушественное влияние на снижение продуктивности целого ряда гнезАовых группировок.

В настояшее время основная проблема степных орлов, гнездяшихся в Оренбуржье, это степные палы, являюшиеся основной причиной неразмножения, или безуспешного размножения птиц. В 2010 г. паиы, в которых сгорели гнёзаа и во многих случаях клаАки или выводки, были причиной неуспеха размножения мия трети гнезАовых участков (29,6 \%) из обшего числа неуспешных, составлявших $71 \%$ от всей выборки гнездовых участков, посешённых в этот год (Карякин и Ар., 2010). В 2015 г. из 45 занятых участков 44,4\% пройдено пожарами, из них 11,1\% восстановились

Успешное гнездо степного орла, построенное из сухой травы на месте сгоревшего гнезда на следуюший год после пожара. Фото И. Карякина.

Successful nest of the Steppe Eagle was built on the site burned nest the following year after the fire. Nest was constructed from dry grass. Photo by I. Karyakin. 


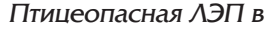
степи Оренбуржья и отанки погибшего на ней степного орла. Фото Е. Барбазюка.

Power line hazardous to birds in the steppe of the Orenburg region (left) and remains of the electrocuted Steppe Eagle who died on this power line (right). Photo by E. Barbazyuk. и были успешными в сезон размножения, a 33,3 \% участков были безуспешными. Аналогичным образом выглялела картина и в 2013 г. - из 42 занятых участков 42,9\% пройдено пожарами, из них 11,9 \% восстановились и были успешными в сезон размножения, а 30,95 \% участков были безуспешными. Т.е. последние годы треть активных гнёзд степных орлов в Оренбуржье сгорает в степных пожарах, причём некоторые с птенцами.

Фактор беспокойства имеет место быть, но в последние годы всё больше сходит на нет, из-за исчезновения гнёзд степных орлов в наиболее населённых Аюдьми районах. Аостаточно низкие показатели (не более $5 \%$ ) имеет также влияние четвероногих хишников и автотранспорта. Но если первый фактор регистрируется на плошалках ежегодно по 1-2 случая, то последний нерегулярно по 1 случаю в 2-3 года.

Гибель степных орлов на АЭП от поражения электротоком была высокой в степях Южного Урала в конце прошлого столетия. Так, на Южном Ураме в 1995-1998 гг. при обследовании АЭП 6-35 кВ было обнаружено 237 погибших особей степного орла, от 1 до 78 особей/100 км минии. В Оренбургской области количество погибших на АЭП птиц превышало результаты визуаиьного учёта живых орлов в 2,5 раза: на 100 км маршрута учтено 13 живых степных орлов и 35 погибших на АЭП (Карякин, 1998). Однако в процессе деградации популяции степного орла уровень его гибели на АЭП снижался. В настояшее время, когла от степного орла освободилась большая часть степной зоны Оренбургской области, гибель на АЭП ре- гистрируется лишь в узкой полосе по границе с Казахстаном.

В 2010 г. в гнездовой период в Оренбургской области осмотрены 4 участка ^ЭП 10 кВ общей протяжённостью 11,8 км, проходящих через местообитания степного орла. На одной из них в Светлинском районе, протяжённостью 5 км, были обнаружены останки 6 степных орлов, погибших преимушественно в период миграции (Аишь одна птица погибла в гнездовой период). В осенний период в Светлинском районе на 2-х осмотренных участках, обшей протяжённостью 22 км зарегистрирована гибель 6 степных орлов, 4-х орловмогильников и одного курганника (Buteo rufinus) (Барбазюк и Ар., 2010; Карякин и $\Delta$ p., 2010).

На 218,96 км АЭП 6-10 кВ, обследованных в июле-августе и октябре 2011 г. в основном в Акбулакском, Беляевском, Аомбаровском, Ясненском, ААамовском, Кваркенском и Светлинском районах Оренбургской области, т.е. в местах гнездования степного орла, обнаружень мишь 2 погибшие птицы, обилие которых составило 0,009 ос./км АЭП, при этом 12 орлов-могильников (0,055 ос./км АЭП) и ешё 7 орлов, не определённых $л о$ вида (Барбазюк, Петришев, 2011; Барбазюк, 2012).

В ходе экспедиции, проходившей с 10 по 20 октября 2014 г., через Предураиьскую (Орловскую) степь и 19 степных памятников природы, в районе которых пройдено 455 км птицеопасных АЭП, останков степного орла вовсе не было обнаружено, только останки 4-х орловмогильников - 1,33 ос./10 км АЭП (Карякин, Вагин, 2015).

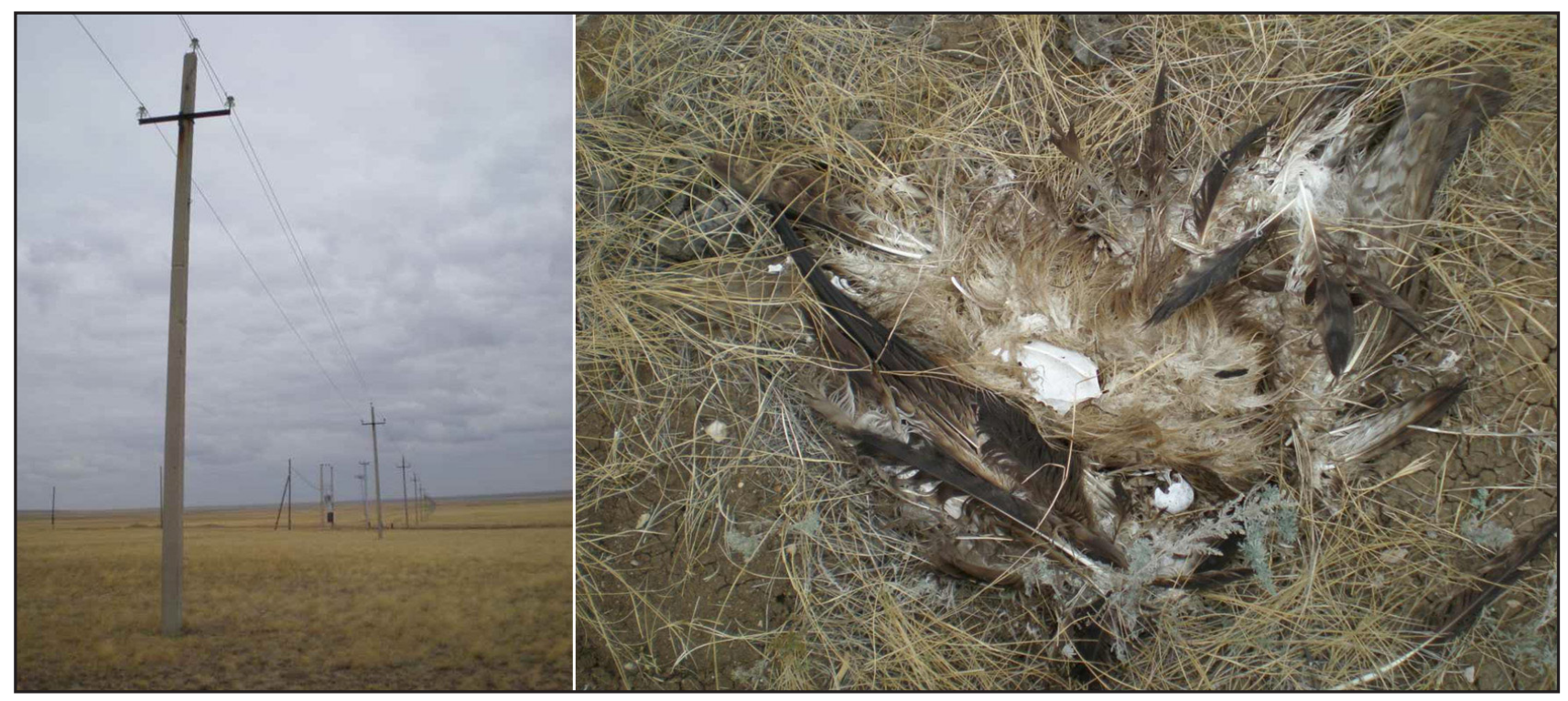




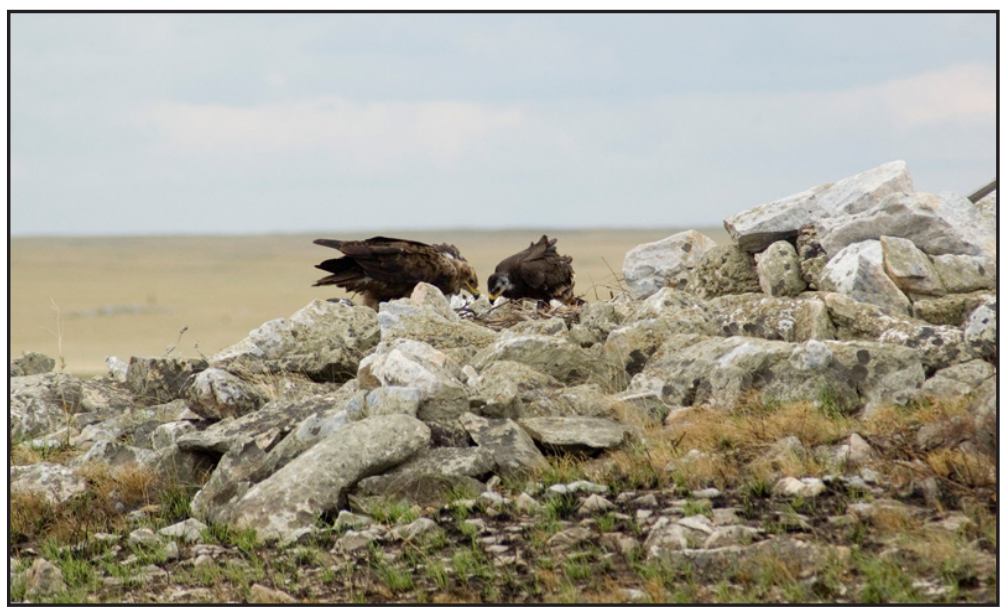

Определённо, с пацением численности степного орла в Оренбуржье, пацает и его уровень гибели на АЭП в области. ОАнако насколько пагубной мяя оренбургских ормов является гибель на АЭП на миграциях и зимовках за пределами области - не известно.

\section{Выводы}

1. За 2010-2015 гг. численность степного орла в Оренбургской области снизилась на 20,6 \%: с 369 (320-447) Ао 293 (266-349) пар.

2. Средняя плотность распределения занятых гнездовых участков степного орла в 2015 г. в "ялре" популяции (на кварцитовых грялах Зауралья) составила 8,6/100 км², на остальной территории (перисерийной) - 1,3 (0,67-2,7)/100 км². В "ялре" популяции гнездится боле $80 \%$ пар степных орлов.

3. Плотность распределения гнездяшихся пар орлов на площалке в "ялре» популяции остаётся стабильной последние 3 года, тогла как на трёх таких плошадках остацьной территории плотность гнездования упала за 5 лет в 2-4 раза. Перисерия значительно быстрее теряет степных орлов, чем "янро" - популяция "тает" на краях и пока остаётся более или менее стабильной в центре.

4. Плотность распределения размножаюшихся пар остаётся низкой: в 2013 и 2015 гг. - в "ялре" популяции 2,0 и 1,8 пар/100 км² соответственно, на остальной территории - 0,29 и 0,73 пар/100 км² соответственно.

5. Успех размножения составия $(n=40)$ 0,55 $\pm 1,04$ птенцов на занятый участок в 2013 г. и $(n=45) 0,40 \pm 0,78$ в 2015 г. Т.е. после 2012 г. успех размножения определённо снижается. Снижается и продуктивность успешных пар. Если в 2013 г. число птенцов в выводках варьировало от 1 до
Успешное гнездо степного орла, построенное из сухой травы на месте сгоревшего гнезда на следуюший год после пожара. Фото И. Карякина.

Successful nest of the Steppe Eagle was built on the site burned nest the following year after the fire. Nest was constructed from dry grass. Photo by I. Karyakin.

3. составляя в среднем $(n=28) 2,15 \pm 0,69$ птенцов на успешное гнезАо, то в 2015 г. - от 1 до 4, составляя в среднем $(n=32)$ $1,68 \pm 0,89$ птенцов на успешное гнездо.

6. Отмечено сушественное увеличение Аоли молодых птиц в размножаюшихся паpax с 21,7 \% в 2012 г. Ао 44,4\% в 2015 г. Рахует то, что в популяции ешё сохраняется ресурс молодых птиц, способных восстанавливать разрушенные пары старых птиц, пусть Ааже за счёт подпитки из Казахстана. Но сама тенденция не даёт оптимизма.

7. Основная наблюдаемая на территории причина низкого успеха размножения - степные пожары в гнездовой периоА. Кроме того, велика вероятность гибели птиц на АЭП. Уничтожение гнёзд скотом или пастушьими собаками, а также фактор беспокойства при выпасе - не слишком значимые факторы в Оренбургской области в связи с низкой пастбишной нагрузкой в местах гнездования степного орла.

\section{Благодарности}

Авторы выражают признательность за непосредственное участие в полевых исследованиях А. Семёнову, С. Бакке, А. Барашковой, И. Смелянскому, Е. Барбазюку, Н. Колесовой и А. Вагину. Отдельная благодарность руководству проекта ПРООН/ ГЭФ/Минприроды России “Совершенствование системы и механизмов управления ООПТ в степном биоме России", без поддержки которого была бы невозможна продуктивная работа в Оренбургской обмасти.

\section{\итература}

Атлас Оренбургской области. Омск, 1993. 40 c. [Atlas of the Orenburg region. Omsk, 1993: 1-40. (in Russian)].

Барбазюк Е.В. О распространении и гнезАовании степных орлов (Aquila rapax) на участках государственного степного заповедника "Оренбургский". - Вестник ОГУ. 2009. № 6. C. 64-66. [Barbazyuk E.V. About distribution and breeding of the Steppe Eagle (Aquila rapax) in clusters of the Orenburgsky State Steppe Nature Reserve. - Bulletin of the 
Orenburg State University. 2009. 6: 64-66. (in Russian)].

Барбазюк Е.В. Птицы и АЭП: выявление фрактов гибели птиц на линиях электропередач 6-10 кВ в степных ландшасртах Оренбуржья. Степи Северной Евразии: Материалы VI Междунар. симп. и VIII Междунар. шк.-семинара «Геоэкологические проблемы степных регионов». Оренбург: ИПК «Газпромпечать» ООО "Оренбурггазпромсервис", 2012. С. 860-863. [Barbazyuk E.V. Birds and Power Lines: study of bird death on power lines 6-10 kV in the Orenburg steppe landscapes. - Steppes of Northern Eurasia: Proceedings of the International Symposium VI and VIII of the International SchoolWorkshop "Geo-ecological problems of the steppe regions". Orenburg, 2012: 860-863. (in Russian)]. URL: http://docs.sibecocenter.ru/programs/raptors/Publ/Barbazuk2012.pdf Аата обрашения: 10.10.2016.

Барбазюк Е.В., Бакка С.В., Барашкова А.Н., Семёнов А.Р., Смелянский И.Э. Итоги предварительного мониторинга гибели пернатых хишников и Аругих видов птиц от поражения током на ^иниях электропередачи в Восточном Оренбуржье, Россия. - Пернатые хишники и их охрана. 2010. № 20. С. 40-47. [Barbazyuk E.V., Bakka S.V., Barashkova A.N., Semenov A.R., Smelyanskiy I.E. The Outcomes of Preliminary Monitoring for Death of Raptors and Other Bird Species Through Electrocution in the Eastern Orenburg District, Russia. - Raptors Conservation. 2010. 20: 40-47]. URL: http://rrrcn.ru/ru/ archives/19201 Аата обрашения: 10.10.2016.

Барбазюк Е.В., Петришев В.П. Оценка гибели птиц на миниях электропередач 6-10 кВ в Оренбургской области метом 2011 года. - Вестник ОГУ. 2011. № 12. С. 31-33. [Barbazyuk E.V., Petrischev V.P. Estimation of bird deaths on power lines $6-10 \mathrm{kV}$ in the Orenburg region in summer 2011. - Bulletin of the Orenburg State University. 2011. 12: 31-33. (in Russian)]. URL: http://rrrcn.ru/wp-content/ uploads/2014/12/9.pdf Аата обрашения: 10.10.2016.

Вербицкая Н.П. Геоморсология Южного Урала и Мугоджар. М.: НеАра, 1974. 84 с. [Verbitskaya N.P. Geomorphology of the South Ural and Mugodzhary. Moscow, 1974: 1-84. (in Russian)].

Гамушин В.М. Степной орёл. - Красная книга Российской Федерации. Т. 2. Животные. М. 2001. C. 434-435. [Galushin V.M. Steppe Eagle. - Red Data Book of Russian Federation. Vol. 2. Animals. Moscow, 2001: 434-435. (in Russian)].

Горчаковский П.А., Рябинина 3.Н. Степная растительность Ураио-Илекского междуречья, ее антропогенная деграхация и проблемы еe oxраны. - Экология. 1981. № 3. С. 9-23. [Gorchakovskiy P.L., Ryabinina Z.N. Steppe vegetation of the Ural and Ilek watershed, its anthropogenic degradation and problems of its protection. Ecology. 1981. 3: 9-23. (in Russian)].

Горчаковский П.А., Рябинина 3.Н. Степи южной части Оренбургской области (УралоИлекское междуречье). - Растительные сообшества Ураяа и их антропогенная деграхация. Сверциовск, 1984. С. 3-64. [Gorchakovskiy P.L., Ryabinina Z.N. Steppes of the Southern part of the Orenburg region (the area between the Ural and Ilek rivers). - Vegetation of the Ural and its anthropogenic degradation. Sverdlovsk, 1984. 3-64. (in Russian)].

Аавыгора А.В. Видовой состав и численность хишных птиц степей юго-западного Предурамья. - Научные основы охраны природы Урала и проблемы экологического мониторинга. Тезисы докиацов областной конференции молоАых учёных и специаиистов. Сверциовск, 1985. C. 15-16. [Davygora A.V. Species composition and population numbers of birds of prey of the steppe of the South-Western Ural. - Scientific basis of Nature Protection of the Urals and environmental monitoring problems. Abstracts of the regional conference of young scientists and specialists. Sverdlovsk, 1985: 15-16. (in Russian)].

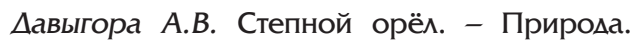
1992. № 3. C. 40-47. [Davygora A.V. Steppe Eagle. - Nature. 1992. 3: 40-47. (in Russian)].

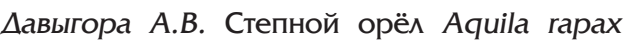
(Temminsk, 1828). - Красная книга Оренбургской области. Оренбург: Оренбургское книжное издательство, 1998. С. 40-41. [Davygora A.V. Steppe Eagle Aquila rapax (Temminsk, 1828). - Red Data Book of the Orenburg region. Orenburg, 1998: 40-41. (in Russian)].

Аохман Г.И. Растительность Мугоджар. М.: ИзА-во АН СССР, 1954. 135 с. [Dokhman G.I. Vegetation of the Mugodzhary. Moscow, 1954: 1-135. (in Russian)].

Ерохина А.A. Почвы Оренбургской области. М.: ИзА-во АН СССР, 1959. 163 с. [Erokhina A.A. Soils of the Orenburg region. Moscow, 1959: 1-163. (in Russian)].

Зарудный Н.A. Орнитологическая фрауна Оренбургского края. - Записки ИмператорСкой Акацемии наук. 1888. Т. 57, прил. № 1. C. 2-338. [Zarudny N.A. Ornithological fauna of the Orenburg region. - Notes of the Imperial Academy of Sciences. 1888. 57. Suppl. 1: 2-338. (in Russian)].

Зарудный Н.А. Аополнения к "Орнитологической фауне Оренбургского края". - Материалы к познанию фауны и флоры Российской империи. ОтА. зоол. 1897. Вып. 3. С. 171-312. [Zarudny N.A. Additions to the "Ornithological fauna of the Orenburg region". - Materials to the knowledge of the fauna and flora of the Russian Empire. Issue Zool. 1897. 3: 171-312. (in Russian)].

Ильина И.С. Растительность сухих степей Орь-Кумакского водораздела (Южный Урах). - 
Вестник АГУ. Сер. геол. и геогр. 1964. Вып. 1, № 4. C. 57-83. [II'ina I.S. Vegetation of the dry steppes on the watershed of the Or and Kumak rivers (Southern Ural). - Bulletin of the Leningrad State University. Series Geology and Geography1964. 1 (4): 57-83. (in Russian)].

Ильина И.С. К вопросу о киассификации комплексной растительности сухих степей Орского Заураиья. - Ботанический журнаи. 1970. 55, № 10. C. 1393-1405. [Il'ina I.S. On the classification of complex vegetation of the dry steppes of the Orsk Trans-Ural region. - Botanical Journal. 1970. 55 (10): 1393-1405. (in Russian)].

Карякин И.В. Пернатые хищники Ураиьского региона. Соколообразные (Falconiformes) и Совообразные (Strigiformes). Пермь, 1998. 483 c. [Karyakin I.V. Raptors of the Ural region. Birds of prey (Falconiformes) and Owls (Strigiformes). Perm, 1998: 1-483. (in Russian)]. URL: http://rrrcn.ru/ru/archives/9173 Аата обрашения: 10.10.2016.

Карякин И.В. Пернатые хишники (методические рекомендации по изучению соколообразных и совообразных). Нижний Новгород, 2004. 351 c. [Karyakin I.V. Raptors (methods on the study of birds of prey and owls). Nizhny Novgorod, 2004: 1-351. (in Russian)]. URL: http://rrrcn.ru/ru/archives/11151 Аата обрашения: 10.09.2016.

Карякин И.В. Аинамика численности степного орла в Самарской области. - Эколого-геограсические исследования в Среднем Поволжье: Материамы научно-практической консеренции по изучению и географии Среднего Поволжья. Казань: ЗАО "Новое знание", 2008. C.143-147. [Karyakin I.V. Trend of the Steppe Eagle population in the Samara region. - Ecological and geographical research in the Middle Volga: Materials of Scientifically-practical Conference on the Study of Geography and Middle Volga. Kazan, 2008: 143-147. (in Russian)].

Карякин И.В. Методические рекомендации по организации мониторинга попумяций степного орла в России и Казахстане. Новосибирск: Акацемическое издательство "Гео", 2012. 89 c. [Karyakin I.V. Methods on the organization of monitoring of the Steppe Eagle populations in Russia and Kazakhstan. Novosibirsk, 2012: 1-89. (in Russian)]. URL: http://rrrcn.ru/ru/archives/12822 Аата обрашения: 10.10.2016.

Карякин И.В. Обзор современного статуса степного орла в мире и в России. - Пернатые хишники и их охрана. 2013. № 26. С. 22-43. [Karyakin I.V. Review of the Modern Population Status of the Steppe Eagle in the World and in Russia. - Raptors Conservation. 2013. 26: 22-43.]. URL: http://rrrcn.ru/ru/archives/19580 $\triangle$ ата обрашения: 10.10.2016.

Карякин И.В. Степной орёл (Aquila nipalensis). - Пернатые хишники Мира (Веб-ГИС «Фа- унистика»). 2015. [Karyakin I.V. Steppe Eagle (Aquila nipalensis). - Raptors of the World (WebGIS “Faunistics”). 2015.]. URL: http://raptors. wildlifemonitoring.ru/\#object/o_id=82019 Аата обрашения: 10.10.2016.

Карякин И.В., Бакка С.В., Барашкова А.Н., Барбазюк Е.В., Горошко О.В., Аапшин Р.А., Николенко Э.Г., Семёнов А.Р., Губин С.В. Оценка численности и основных экологических факторов, влияюших на состояние популяций степного орла в пилотных степных региона России (Оренбургская область и Забайкаиьский край). Окончательный технический отчёт по Контракту 104/2010 с ПРООН от “01" июня 2010 г. Новосибирск, 2010. 29 с. [Karyakin I.V., Bakka S.V., Barashkova A.N., Barbazyuk E.V., Goroshko O.V., Lapshin R.D., Nikolenko E.G., Semenov A.R., Gubin S.V. Estimation number of the Steppe Eagle populations and the main ecological factors that influence on the eagles in the steppe regions in Russia (Orenburg Region and Zabaikalskiy Kray). The final technical report on the Contract with the UNDP 104/2010 by "01" June 2010. Novosibirsk, 2010: 1-29. (in Russian)]. URL: http://rrrcn.ru/ru/archives/9874 Аата обрашения: 10.09.2016.

Карякин И.В., Вагин А.А. Гибель птиц на АЭП и степные ООПТ Оренбургской области: ситуация не улучшилась. - Степной бюметень. 2015. № 43-44. C. 47-52. [Karyakin I.V., Vagin A.A. The death of birds on power lines and Steppe Protected Areas in the Orenburg region: the situation has not improved. - Steppe Bulletin. 2015. 43-44: 47-52 (in Russian)]. URL: http:// savesteppe.org/ru/archives/12114 Аата обрашения: 10.09.2016.

Карякин И.В., Коваченко А.В., Барашкова А.Н. Мониторинг гнездовых группировок степного орла в трансграничной зоне России и Казахстана в 2012 году. - Пернатые хишники и их охрана. 2013. № 26. С. 61-83. [Karyakin I.V., Kovalenko A.V., Barashkova A.N. Monitoring of the Steppe Eagle Populations in the TransBorder Zone of Russia and Kazakhstan in 2012. - Raptors Conservation. 2013. 26: 61-83]. URL: http://rrrcn.ru/ru/archives/19591 Аата обрашения: 10.09.2016.

Карякин И.В., Коваиенко А.В., Карпов А.Г., Барашкова А.Н. Технический отчет о результатах выполнения работ по проекту «Разработка и апробирование программы мониторинга популяции степного орла в трансграничной зоне России и Казахстана (Оренбургской обмасти РФ, Актюбинской и Запацно-Казахстанской областей РК)". Нижний Новгород, 2012. 45 c. [Karyakin I.V., Kovalenko A.V., Karpov A.G., Barashkova A.N. Report about results of project "Development and approbation of the program on monitoring of the Steppe Eagle population in the transboundary zone of Russia and Kazakhstan (Orenburg Region of Russia, Actobe and 
Western-Kazakhstan Regions of Kazakhstan)". N.Novgorod, 2012: 1-45. (in Russian)]. URL: http://rrrcn.ru/ru/archives/19591 Аата обрашения: 10.09.2016.

Карякин И.В., Козлов А.А. Предварительный камастр птиц Челябинской области. Новосибирск, 1999. 421 с. [Karyakin I.V., Kozlov A.A. Preliminary inventory of bird of the Chelyabinsk region. Novosibirsk, 1999: 1-421. (in Russian)].

Карякин И.В., Паженков А.С. Хишные птицы Самарской области. Книга-фотоамьбом. Самаpa, 2008. 66 c. [Karyakin I.V., Pazhenkov A.S. Raptors of the Samara region. Samara, 2008: 1-66. (in Russian)]. URL: http://rrrcn.ru/ru/archives/4507 Аата обрашения: 10.09.2016.

Колтыпин С.Н. Верхнемеловые отложения Урало-Эмбенской солянокупольной области, юго-западного Приуралья и Примугоджарья. - Труды ВНИГРИ. 109. А.: ГНТИ нестяной и горно-топливной китературы, 1957. 218 с. [Koltypin S.N. Upper Cretaceous deposits of the Ural-Emba salt-dome area of the South-Western Ural and Mugodzhary regions. - Proceedings of the VNIGRI. 109. Leningrad, 1957: 1-218. (in Russian)].

Крашенинников И.М. Физико-геограсические районы Южного Урала. 1. Предгорья восточного скиона и прилегающие части пенепленов. Сер. Ураиьская. Вып. 7. М.;А.: ИзА-во AH CCCP, 1939. 109 c. [Krasheninnikov I.M. The physical-geographical areas of the Southern Urals. 1. The foothills of the eastern slope and the adjacent part of peneplain. Vol. 7. MoscowLeningrad, 1939: 1-109. (in Russian)].

Матяшенко Г.В. Аинамика растительности на меловых обнажениях Подураиьского плато. Новосибирск: Наука, 1985. 110 с. [Matyashenko G.V. Vegetation trend on the chalky outcrops Poduralskoe Plateau. Novosibirsk, 1985: 1-110. (in Russian)].

Мильков Ф.Н., Гвоздецкий Н.А. Физическая география СССР. М.: Мысаь, 1976. 448 с. [Milkov F.N., Gvozdetskiy N.A. Physical geography of the USSR. Moscow, 1976. (in Russian)].

Наумов A.A. Основные генетические типы рельеса южной части Урало-Тобольского межАуречья и их связь с тектоническими структурами - Геоморсология и новейшая тектоника Волго-Уральской области и Южного Урала. Усра, 1960. С. 315-322. [Naumov A.D. The main genetic types of relief of the southern part of the Ural-Tobol watershed and their relationship with tectonic structures. - Geomorphology and Modern Tectonics of the Volga-Ural region and the Southern Urals. Ufa, 1960: 315-322. (in Russian)].

Райский А.П. Животный мир Чкамовской обмасти. - Очерки фризической геограсии Чкаловской области. Чкалов, 1951. С. 157-202. [Rayskiy A.P. Animals of the Chkalov region. Notes on physical geography of the Chkalov re- gion. Chkalov, 1951: 157-202. (in Russian)].

Самигулин Г.М. Птицы. - Степной заповеАник "Оренбургский»: Физико-геограсическая и экологическая характеристика. Екатеринбург: УрО РАН, 1996. С. 83-99. [Samigulin G.M. Birds. - Orenburgskiy Steppe State Nature Reserve: Physico-geographical and ecological characteristics. Ekaterinburg, 1996: 83-99. (in Russian)].

Сасронова И.Н. Растительный покров степной части Подураиьского плато. - Современные проблемы биогеографии. А., 1980. С. 60-68. [Safronova I.N. The vegetation cover of the steppe part of the Poduralskoe plateau. Modern problems of biogeography. Leningrad, 1980: 60-68. (in Russian)].

Сваричевская 3.А. Геоморфология Казахстана и Средней Азии. А.: ИзА-во Ленинградского ун-та, 1965. 296 с. [Svarichevskaya Z.A. Geomorphology of Kazakhstan and Middle Asia. Leningrad, 1965: 1-296. (in Russian)].

Симак С.В. Фауна позвоночных урочища «Грызлы" (Таловская степь). - Животный мир Южного Урала. Оренбург, 1990. С. 92-93. [Simak S.V. Vertebrate fauna of the tract "Gryzly" (Talovskaya steppe). - Animals of the Southern Ural. Orenburg, 1990: 92-93. (in Russian)].

Хомутова М.С. Растительность Зауралья Чка^овской области. - Ученые записки МГПИ. 1956. Т. 97. Вып. 3. С. 3-41. [Khomutova M.S. Vegetation of the Trans-Urals of the Chkalov region. - Scientific notes of the Moscow State Pedagogical Institute. 1956. 97 (3): 3-41. (in Russian)].

Хомутова М.С. Ковыльные степи Заурамья Оренбургской области. - Ученые записки МГПИ. 1965. Т. 212. С. 58-81. [Khomutova M.S. Feather grass steppes of the Trans-Urals of the Orenburg region. - Scientific notes of the Moscow State Pedagogical Institute. 1965. 212: 5881. (in Russian)].

Чибилев А.А. Птицы Оренбургской области и их охрана. Екатеринбург: УИФ "Наука", 1995. 62 c. [Chibilev A.A. Birds of the Orenburg region and their conservation. Ekaterinburg, 1995: 1-62. (in Russian)].

BirdLife International. Aquila nipalensis. The IUCN Red List of Threatened Species 2015: e.T22696038A80351871. 2015. URL: http:// dx.doi.org/10.2305/IUCN.UK.2015-4.RLTS. T22696038A80351871.en. Downloaded on 01 October 2016.

Clark W.S. Ageing Steppe Eagles. - Birding World. 1996. 9: 269-274.

Forsman D. The Raptors of Europe and the Middle East: A Handbook of Field Identification. Christopher Helm, 2008: 1-589.

Nazarov P.S. Recherches zoologiques des steppes de Kirguis. - Bull. Societe Imperiale des Naturalistes de Moscou. 1886. LXII (4): 338382. URL: http://www.biodiversitylibrary.org/ page/34271796 Аата обрашения: 10.09.2016. 